\title{
Analysis of RNA methylation by phylogenetically diverse Cfr radical SAM enzymes reveals an iron-binding accessory domain in a clostridial enzyme
}

\author{
James D. Gumkowski ${ }^{1}$, Ryan J. Martinie ${ }^{1, \dagger}$, Patrick S. Corrigan ${ }^{1}$, Juan Pan ${ }^{1}$, Matthew R. \\ Bauerle $^{1, \#}$, Mohamed Almarei ${ }^{2}$, Squire J. Booker ${ }^{1,2,3}$, Alexey Silakov ${ }^{1}$, Carsten Krebs ${ }^{1,2,{ }^{*} \text {, }}$ \\ Amie K. Boal ${ }^{1,2,{ }^{*}}$ \\ ${ }^{1}$ Department of Chemistry, The Pennsylvania State University, University Park, PA 16802; \\ ${ }^{2}$ Department of Biochemistry and Molecular Biology, The Pennsylvania State University, \\ University Park, PA 16802; \\ ${ }^{3}$ Howard Hughes Medical Institute, The Pennsylvania State University, University Park, PA, \\ 16802.
}

\begin{abstract}
Cfr is a radical $S$-adenosylmethionine (SAM) RNA methylase linked to multi-drug antibiotic resistance in bacterial pathogens. It catalyzes a chemically challenging C-C-bond forming reaction to methylate $\mathrm{C} 8$ of A2503 [Escherichia coli $(E c)$ numbering) of $23 S$ ribosomal RNA during ribosome assembly. The cfr gene has been identified as a mobile genetic element in diverse bacteria and in the genome of select Bacillales and Clostridiales species. Despite the importance of $\mathrm{Cfr}$, few representatives have been purified and characterized in vitro. Here we show that $\mathrm{Cfr}$ homologs from Bacillus amyloliquefaciens, Enterococcus faecalis, Paenibacillus lautus, and Clostridioides difficile act as C8 adenine RNA methylases in biochemical assays. C. difficile Cfr contains an additional Cys-rich C-terminal domain that binds a mononuclear $\mathrm{Fe}^{2+}$ ion in a rubredoxin-type $\mathrm{Cys}_{4}$ motif. The $\mathrm{C}$-terminal domain can be truncated with minimal impact on $C$. difficile $\mathrm{Cfr}$ activity, but turnover is diminished upon disruption of the $\mathrm{Fe}^{2+}$ binding site by $\mathrm{Zn}^{2+}$ substitution or ligand mutation. These findings indicate an important purpose for the observed Cterminal iron in the native fusion protein. Bioinformatic analysis of the $C$. difficile $\mathrm{Cfr}$ Cys-rich domain shows that it is widespread ( 1000 homologs) as a stand-alone gene in pathogenic or commensal bacilli and clostridia, with $>10 \%$ encoded adjacent to a predicted radical-SAM RNA methylase. Although the domain is not essential for in vitro $C$. difficile Cfr activity, genomic co-
\end{abstract}

\footnotetext{
“To whom correspondence may be addressed: ckrebs@psu.edu, akb20@psu.edu.

$\dagger$ Present address: Department of Chemistry, Princeton University, Princeton, NJ, 08544.

\#Present address: Exemplify BioPharma, 3000 Eastpark Rd., Cranbury, NJ, 08512.

ACCESSION CODES

WP_002578771 - Clostridioides difficile str. QCD63q42

WP_015735625 - Paenibacillus lautus sp. Y412MC10

WP_013351126 - Bacillus amyloliquefaciens str. DSM-7 (ATCC 23350)

WP_002405682 - Enterococcus faecalis str. TX0635

AIT41446 - Staphylococcus aureus (plasmid)

WP_003483120 - Clostridium sporogenes str. ATCC 15579

Supporting information includes supplementary tables S1-S4, and supplementary figures S1-9.
} 
occurrence and high abundance in the human microbiome suggests a possible functional role for a specialized rubredoxin in certain radical-SAM RNA methylases with relevance to human health.

\section{Graphical Abstract}

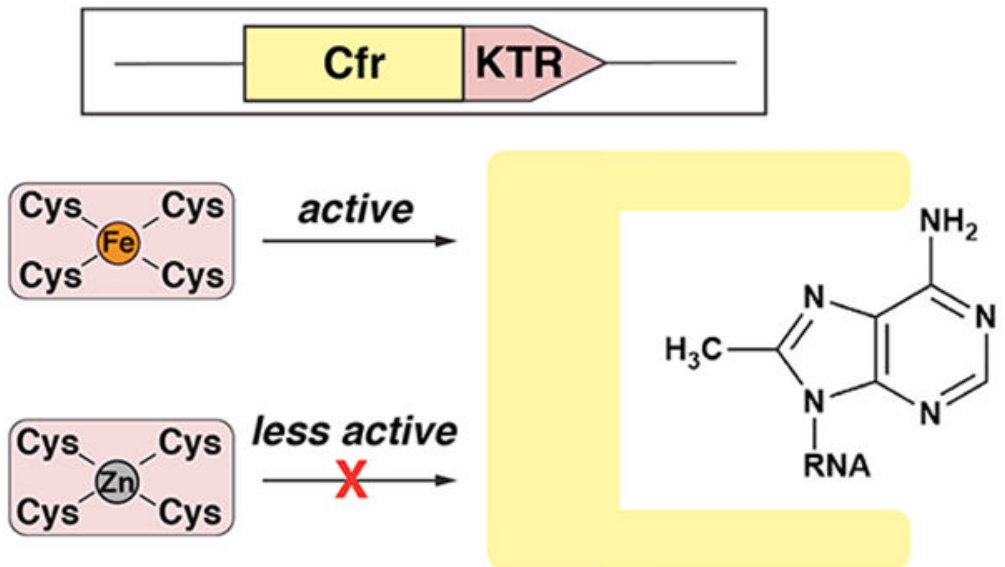

\section{INTRODUCTION}

Radical $S$-adenosylmethionine (SAM) enzymes compose one of the largest enzyme superfamilies defined to date, with more than 400,000 members. ${ }^{1}$ Radical SAM enzymes are essential in primary anaerobic metabolism and in the synthesis of diverse secondary metabolites. ${ }^{2,3}$ Nucleic acid modification is a third central function of radical SAM proteins, and this activity has been demonstrated in all three domains of life. ${ }^{4,5} \mathrm{~A}$ pair of adenine RNA methylases, RlmN and Cfr, are among the most widespread and well-characterized radical SAM nucleic acid modification enzymes in bacteria. ${ }^{6-8}$ Although originally discovered to methylate $\mathrm{C} 2$ of A2503 in ribosomal RNA (rRNA), a base located in the peptide exit tunnel of the peptidyltransferase center of the bacterial ribosome, RlmN also modifies six additional tRNA substrates at A37. ${ }^{9}, 10$ In Escherichia coli, RlmN is nonessential, but its activity improves translational fidelity and organism fitness. ${ }^{10}$ More than 20,000 RlmN homologs have been identified in the sequenced genomes of prokaryotes of diverse origin. ${ }^{1}$ Related Cfr enzymes are smaller in number, with approximately 200 homologs annotated in Interpro and other protein sequence databases. Cfrs were initially found encoded as mobile genetic elements in staphylococcal pathogens, ${ }^{9}$ and Staphylococcus aureus ( $\mathrm{Sa}$ ) $\mathrm{Cfr}$ has been characterized extensively in vitro. The enzyme methylates $\mathrm{C} 8$ of A2503 in $23 S \mathrm{rRNA}$, and this modification confers resistance to multiple classes of antibiotics. ${ }^{11}$ Although quite relevant to human health, few of the other Cfrs have been characterized in vitro, and the structure of the enzyme is not known.

The common methyl donor SAM is the source of the newly appended methyl carbon in $\mathrm{R} \operatorname{lmN}$ and $\mathrm{Cfr}^{6}{ }^{6}$ In their function as C-methylases, $\mathrm{R} \mathrm{mN}$ and Cfr perform a chemically challenging $\mathrm{C}-\mathrm{C}$ bond forming reaction involving functionalization of inert $s p^{2}$-hybridized C-H bonds. ${ }^{12}$ This activity cannot be accomplished by the standard polar mechanism characteristic of SAM- dependent methyl transferases. Instead, radical chemistry is required and enabled here by a second SAM-dependent activity in $\mathrm{R} \operatorname{mNN}$ and $\mathrm{Cfr}$ - transient 
formation of a potently oxidizing 5'-deoxyadenosyl radical (5'-dA $\bullet$ ). $6,7,15$ Nearly all enzymes in the radical SAM superfamily share this intermediate, ${ }^{13}, 16$ generated by reduction of a SAM-coordinated $[4 \mathrm{Fe} 4 \mathrm{~S}]^{2+}$ cluster that, in turn, triggers reductive cleavage of the coordinated cosubstrate. In RlmN and Cfr, the 5' -dA • abstracts a hydrogen atom from a Cys-appended $-\mathrm{CH}_{3}$ group (mC338, $\mathrm{Sa} \mathrm{Cfr}$ numbering) to yield a methylene radical (Figure 1). ${ }^{7}$ Radical addition to the adenine nucleobase at either $\mathrm{C} 2$ or $\mathrm{C} 8$ generates a transient protein-RNA crosslink containing an unpaired electron on the adenine nucleobase.

17 Proton transfer from C2/C8 to an active site base, a second conserved Cys residue (C105, $\mathrm{Sa}$ Cfr numbering), resolves the crosslink. ${ }^{14,18,19}$ This step is proposed to yield a thiyl radical at the $\mathrm{C}$-terminal $\mathrm{C} 338$, which must be reduced prior to subsequent turnover. ${ }^{14}$ Interestingly, several other redox-neutral radical SAM C-C bond forming enzymes also oxidize an active site Cys side chain ${ }^{12}$ to balance the initial two-electron reductive cleavage of SAM. ${ }^{12,20}$ In these systems, auxiliary iron-sulfur cluster or cobalamin-binding domains are often present and proposed to provide necessary reducing equivalents. ${ }^{12}$ The RImN and Cfr homologs characterized to date are distinct in that they do not harbor an obvious universal dedicated thiyl radical reductant.

The proposed mechanism of the RNA methylases has been validated through spectroscopic and biochemical analysis of $E$. coli $\mathrm{RlmN}$ and $S$. aureus $\mathrm{Cfr}{ }^{7,}$ 14, 17, 21 The two key catalytic Cys residues (C338 and C105) are strictly conserved in these homologs and all others identified to date. X-ray crystal structures of $E$. coli $\mathrm{RlmN}$ have been solved, both alone 22 and in complex with tRNA, ${ }^{18}$ the latter obtained by trapping the covalent protein-RNA intermediate via substitution of $\mathrm{C} 118$ with a non-functional alanine (C105A equivalent). 18, 22 To date, no structures have been reported of either enzyme in complex with a ribosomal RNA substrate. Additionally, Cfr homologs have not been structurally characterized in any form, even though such information would be useful in the design of inhibitors that could rescue the activities of existing antibiotics to which Cfr currently confers bacterial resistance.

To identify Cfr candidates suitable for ongoing structural studies, we performed phylogenetic analyses of $\mathrm{Sa} \mathrm{Cfr}$ homologs identified in database searches. As reported previously, at least four distinct groups of enzymes emerge, including a clostridial clade classified as Cfr-like. ${ }^{23}$ Cfr-like homologs from Clostridium sporogenes ${ }^{23}$ and Clostridium phytofermantas ${ }^{24}$ have been proposed to harbor a different, still undefined, activity because they fail to confer antibiotic resistance and lack C8 methylation activity in primer extension assays when overexpressed in E. coli. ${ }^{23,24}$ Here we show that heterologously expressed and purified Cfr homologs from Bacillus amyloliquefaciens (Ba), Enterococcus faecalis (Ef), Paenibacillus lautus $(P I)$, and Clostridioides difficile $(C d)$ are capable of rRNA methylation in vitro. All four enzymes contain a full occupancy [4Fe-4S] cluster in their wild-type (wt) forms, as established by Mössbauer spectroscopy and other analytical techniques. All four homologs modify A2503 at C8 but with different rates. The enzymes also vary in their capacity for subsequent $\mathrm{C} 2$ methylation of the same base. $C$. difficile Cfr is active as a C8 methylase with limiting RNA substrate but exhibits distinctly slower methylation when challenged with excess RNA. Interestingly, this Cfr homolog contains a unique $~ 50$-aminoacid Cys-rich C-terminal extension related by sequence to a much larger family of clostridial and streptococcal proteins of unknown function. In $C d \mathrm{Cfr}$, this domain binds a mononuclear 
$\mathrm{Fe}^{2+}$ ion in a 4-Cys binding site with a midpoint potential $\left[\mathrm{Fe}^{2+} / \mathrm{Fe}^{3+}\right.$ couple $]$ of $+105 \mathrm{mV}$ vs. NHE, similar to those of rubredoxin electron transfer proteins. Substitution of the Cterminal metal binding site with $\mathrm{Zn}^{2+}$, or Cys $\rightarrow$ Ala mutation of one of the predicted $\mathrm{Fe}^{2+}$ ligands, significantly impedes turnover. However, complete removal of the C-terminal domain has no effect on in vitro activity. While only a few select $\mathrm{Cfr}$ homologs contain a Cys-rich C-terminal fusion, genome neighborhood analysis of the larger family of standalone domains reveals that $>10 \%$ are encoded next to clostridial radical SAM enzymes. The findings suggest that these iron-binding rubredoxin-like proteins are widespread in Clostridiales and, to a lesser extent, Bacillales organisms, including pathogens and human commensals. While the metal-binding domain is dispensable for in vitro Cfr activity in $C$. difficile, an essential role for this specialized rubredoxin (or another protein partner) in vivo could explain the reported lack of RNA methylation activity in other clostridial Cfr enzymes.

\section{MATERIALS AND METHODS}

\section{Materials.}

Kanamycin was obtained from Teknova (Hollister, CA). Ampicillin was purchased from Dot Scientific (Burton, MI). $N$-(2-hydroxyethyl)piperazine- $N^{\prime}$-2-ethanesulfonic acid (HEPES), DNaseI (RNase-free), Bradford reagent, and His-Pur $\mathrm{Co}^{2+}-\mathrm{TALON}$ resin were obtained from Thermo Fisher Scientific (Waltham, MA). Sodium sulfide, 2-mercaptoethanol, sodium dithionite, glucose, $S$-adenosylmethionine, and p1 nuclease from Penicillium citrinum were purchased from Sigma Aldrich (St. Louis, MS). Iron (III) chloride hexahydrate was acquired from BDH Analytical Chemicals, VWR (Radnor, PA). DL-dithiothreitol (DTT) was obtained from Alfa Aesar (Tewksbury, MA). ${ }^{57} \mathrm{Fe}$ metal (98\%) was purchased from Isoflex USA (San Francisco, CA). Bovine serum albumin (BSA), Xhol, NdeI, antarctic phosphatase, Q5 DNA polymerase, and T4 DNA ligase were obtained from New England Biolabs (Ipswich, MA). PD-10 and HiPrep Sephacryl 16/60 S200 columns were purchased from GE Healthcare (Little Chalfont, United Kingdom).

\section{Phylogenetic analysis of Cfrs.}

Homologs were identified by BLASTp analysis using $\mathrm{Sa} \mathrm{Cfr}$ as the query against the nonredundant protein sequence database (NCBI, accessed March 2018) with default search parameters. The top 500 matches were aligned in MUSCLE after consolidation with ExPASy ( $<98 \%$ minimum identity filter in the decrease redundancy tool) to remove duplicate sequences. The final pool contained 361 unique sequences. ${ }^{25}, 26$ The program MEGA $7^{27}$ was used to compute a phylogenetic tree using the minimum evolution method with the JTT model of substitution, allowance of pairwise deletions, and closest neighbor set to level $=2$. Bootstrap values were computed from 1000 replicates.

\section{Cloning and overexpression of full-length Cfr proteins.}

DNA sequences encoding genes for the Cfrs selected for study (Table S1) (with the exception of $C d \mathrm{Cfr}$ ) were codon-optimized for over-expression in $E$. coli, synthesized, and inserted into a pMK-T vector (GeneArt). PCR primers (Table S1) were designed with Primer3 and appended at the 5'-end with NdeI and XhoI restriction sites. The coding sequences were amplified by PCR using Q5 DNA polymerase. The PCR products were 
digested using $N d e I$ and $X h o I$ restriction enzymes, purified by gel electrophoresis, reisolated using an Omega Biotek gel extraction kit, and ligated into pET26b. The $C$. difficile cfr overexpression plasmid was constructed using the Gibson assembly method. ${ }^{28}$ The gene was codon optimized for overexpression in E. coli and synthesized in two pieces, each containing 20 base-pair regions that overlap with the pET26b vector and with each other.

The gene and linearized vector were combined with a 5'-exonuclease, DNA polymerase, and DNA ligase to allow for pET26b-cfr assembly. All four pET26b-cfr sequences were verified by Sanger sequencing at the Pennsylvania State University Nucleic Acid Facility, and the coding regions can be found in Table S1 of the Supporting Information. All plasmids additionally encode a C-terminal His $_{6}$-tag with a short two amino acid (-Leu-Glu-) linker.

The C363A $C d$ Cfr variant was generated by inverse PCR using a new forward primer containing the relevant substitution in the annealing region (Table S1). Amplification was performed using the pET26b/Cfr $(C d)$ plasmid (generated as described above) as the DNA template. $D p n$ I digestion was used to remove the original template DNA and the vector was circularized by ligation with T4 DNA ligase.

Overexpression of all constructs was accomplished in E. coli BL21(DE3) cells cotransformed with pET26b-cfr and pDB1282, ${ }^{29}$ the latter a vector containing inducible ironsulfur cluster assembly machinery. Successful transformants were selected on kanamycin $(50 \mu \mathrm{g} / \mathrm{mL})$ and ampicillin $(100 \mu \mathrm{g} / \mathrm{mL})$ supplemented LB plates. $1.5 \mathrm{~L}$ cultures of the overexpression strains were grown shaking $(180 \mathrm{rpm})$ at $37{ }^{\circ} \mathrm{C}$ in $\mathrm{M} 9$ minimal medium supplemented with kanamycin $(50 \mu \mathrm{g} / \mathrm{mL})$, ampicillin $(100 \mu \mathrm{g} / \mathrm{mL})$, iron (III) chloride (30 $\mu \mathrm{M})$, and L-cysteine $(300 \mu \mathrm{M})$ to maximize iron-sulfur cluster incorporation. ${ }^{30}$ Growths for samples suitable for Mössbauer analysis utilized ${ }^{57} \mathrm{Fe}$ dissolved in $1 \mathrm{M} \mathrm{H}_{2} \mathrm{SO}_{4}$. At an $\mathrm{OD}_{600}$ $=0.3$, $\mathrm{L}$-arabinose was added [final concentration $0.08 \%(\mathrm{~W} / \mathrm{V})$ ] to induce overexpression of the genes harbored on the pDB1282 plasmid. At an $\mathrm{OD}_{600}=0.6$, IPTG was added to a final concentration of $100 \mu \mathrm{M}$ to induce overexpression of the pET26b-cfr. After incubation overnight at $18{ }^{\circ} \mathrm{C}$ at $180 \mathrm{rpm}$, cells were pelleted by centrifugation at $5000 \mathrm{~g}$ for $10 \mathrm{~min}$ at $4{ }^{\circ} \mathrm{C}$. Approximately $3.2 \mathrm{~g}$ cell paste was obtained per liter of culture. Cell paste was flashfrozen in liquid nitrogen and stored at $-80^{\circ} \mathrm{C}$. Flavodoxin and flavodoxin reductase were purified as described previously. ${ }^{30}$

\section{Purification of full-length Cfrs.}

All purification steps were performed anaerobically in an anoxic chamber with a mixed $\mathrm{H}_{2} / \mathrm{N}_{2}$ atmosphere (Coy Laboratory Products). Cells were resuspended in lysis buffer (50 mM HEPES pH 7.5, $300 \mathrm{mM} \mathrm{KCl,} 4 \mathrm{mM}$ imidazole, $10 \mathrm{mM} \mathrm{MgCl}_{2}, 10 \%$ ( $/ / \mathrm{v}$ ) glycerol, 10 $\mathrm{mM} \beta$-mercaptoethanol) in a nickel-coated beaker containing $1 \mathrm{mg} / \mathrm{mL}$ lysozyme, 100 $\mu \mathrm{g} / \mathrm{mL}$ DNase, and $1 \mathrm{mM}$ phenylmethylsulfonyl fluoride (PMSF). The suspension was stirred at room temperature for $30 \mathrm{~min}$ and lysed by sonication (QSonica Q500, $10 \mathrm{~s}$ pulse, $30 \mathrm{~s}$ rest, $60 \%$ amplitude) on ice. The resulting cell debris was pelleted by centrifugation at $11,300 \mathrm{~g}$ at $4{ }^{\circ} \mathrm{C}$ for $1.25 \mathrm{~h}$ in a sealed centrifuge bottle. The supernatant was applied to $\mathrm{Co}^{2+}$-TALON resin. Protein fractions were eluted in $50 \mathrm{mM}$ HEPES, pH 7.5, $300 \mathrm{mM} \mathrm{KCl}$, $300 \mathrm{mM}$ imidazole, $10 \mathrm{mM} \mathrm{MgCl}_{2}, 30 \%$ ( $\left.v / v\right)$ glycerol, $10 \mathrm{mM} \beta$-mercaptoethanol. Reconstitution of $[4 \mathrm{Fe} 4 \mathrm{~S}]^{2+}$ clusters was performed on ice for all samples except $C s \mathrm{Cfr}$. 
Protein samples $(200 \mu \mathrm{M})$ were exchanged into gel-filtration chromatography buffer [10 $\mathrm{mM}$ HEPES pH 7.5, $500 \mathrm{mM} \mathrm{KCl,} 5 \mathrm{mM}$ DTT, $10 \mathrm{mM} \mathrm{MgCl} 2,25 \%$ ( $V / v)$ glycerol] and incubated for $30 \mathrm{~min}$ at room temperature. Iron (III) chloride $(800 \mu \mathrm{M})$ was added to the solution, which was subsequently incubated for $1 \mathrm{~h}$ at room temperature. Sodium sulfide was added to the solution (to a final concentration of $800 \mu \mathrm{M}$ ) in six equal volumes over the course of $2 \mathrm{~h}$. The solution was allowed to incubate on ice overnight. A PD-10 column was used to remove excess iron and sulfide. Size-exclusion chromatography was performed using a Sephacryl S200 column. Protein concentrations were determined by Bradford analysis with correction factors (Molecular Structural Facility at UC Davis) of 0.891 ( $C d$ ), $0.627(B a), 0.828(E f)$, and $0.687(P I)$. Iron-sulfur cluster incorporation (Table 2) was assessed by measuring the number of iron equiv per protein with the ferrozine assay. ${ }^{31}$

\section{Overexpression and purification of truncated and single-site $\mathrm{Cd} C \mathrm{Cfr}$ variant proteins.}

Truncated $C d$ Cfr variants consisting of either the radical SAM domain (Cd-N), residues 1345 , or the rubredoxin/KTR domain (Cd-C), residues 346-416, were generated using the approach described above (see Table S1 for primer sequences). A C363A variant (M) of fulllength $C d \mathrm{Cfr}$ was generated as described. Overexpression and purification of all variant proteins was performed as described for the wt enzymes. Zinc replacement of the C-terminal metal binding site in $\mathrm{Cd}-\mathrm{C}$ was accomplished by addition of $\mathrm{ZnCl}_{2}(7 \mathrm{mM})$ to minimal medium cultures both upon initial inoculation and at $\mathrm{OD}_{600} \sim 0.6$ in place of iron supplementation. Both iron- and zinc-bound versions of $\mathrm{Cd}-\mathrm{C}$ were overexpressed without pDB1282 present, and the iron-sulfur cluster reconstitution step was omitted. Iron and zinc occupancies were determined by inductively coupled plasma optical emission spectroscopy (ICP-OES) at the Pennsylvania State University Laboratory for Isotopes and Metals in the Environment (LIME). Cd-C contains 0.45 equiv iron, $\mathrm{Cd}-\mathrm{Z}$ contains 0.36 equiv zinc, and full-length $C d \mathrm{C} 363 \mathrm{~A}$ contains 2.53 equiv iron.

\section{Synthesis and purification of RNA.}

To generate a 155 nucleotide (nt) fragment of $E c 23 S$ rRNA corresponding to A2454-G2608 (Figure S1), previously shown to be efficiently methylated by $\mathrm{SaCfr},{ }^{5}$ a DNA template was amplified using primers 2454 and 2608 (Table S1), and transcribed in a reaction with T7 RNA polymerase $(500 \mu \mathrm{g} / \mathrm{mL})$. The transcription reaction was performed in $30 \mathrm{mM}$ Tris, $\mathrm{pH}$ 8.4, $20 \mathrm{mM}$ DTT, $36 \mathrm{mM} \mathrm{MgCl} 2,0.01 \%$ ( $w / v)$ Triton X-100, $2 \mathrm{mM}$ spermidine, $2 \mathrm{mM}$ NTPs (4 mM GTP). The template DNA PCR product was diluted to a final concentration of $5 \mathrm{ng} / \mathrm{uL}$ and incubated for $3 \mathrm{~h}$ at $37^{\circ} \mathrm{C}$ with the components above. DNaseI was added to the solution (to a final concentration of $0.005 \mathrm{U} / \mu \mathrm{L}$ ) and incubated at $37^{\circ} \mathrm{C}$ for an additional hour. EDTA ( $\mathrm{pH} 8.5$ ) was added to a final concentration of $50 \mathrm{mM}$, and the solution was frozen at $-20{ }^{\circ} \mathrm{C}$ for at least $2 \mathrm{~h}$. Full-length 155 mer RNA transcripts were purified under anaerobic conditions (Coy Laboratory Products) by PD-10 column equilibrated in filtered nanopure water. RNA concentrations were determined by UV-visible spectrophotometry $\left(\varepsilon_{260}=1.87 \mu \mathrm{m}^{-1} \mathrm{~cm}^{-1}\right) .{ }^{17}$ The A2503G variant RNA was prepared similarly, except the first PCR step was performed with a synthetic template (Integrated DNA Technologies, see Supporting information for sequence) containing the desired base change. 


\section{RNA methylation activity assays with limiting substrate.}

In experiments using a protein-based low-potential reducing system [flavodoxin (Flv), flavodoxin reductase (Flx), and NADPH], RNA methylation was assayed in a total volume of $150 \mu \mathrm{L}$ at room temperature in an anoxic glovebox (Coy Laboratory Products) over a time course of $2.75 \mathrm{~h}$. Samples contained $48 \mu \mathrm{M}$ Cfr and $50 \mu \mathrm{M} 155 \mathrm{mer}$ RNA in $100 \mathrm{mM}$ sodium EPPS, pH 8.0, $10 \mathrm{mM} \mathrm{MgCl}_{2}, 12.5 \%$ ( $\left.v / v\right)$ glycerol, $250 \mathrm{mM} \mathrm{KCl}, 200 \mu \mathrm{M} \mathrm{Flv}, 20 \mu \mathrm{M}$ Flx, and $2 \mathrm{mM}$ NADPH. The solution was incubated at room temperature for $5 \mathrm{~min}$ before initiating the reaction by addition of SAM to a final concentration of $1 \mathrm{mM}$. At designated time points, a $10 \mu \mathrm{L}$ aliquot of the reaction solution was removed and added to $10 \mu \mathrm{L}$ of quench solution containing $250 \mu \mathrm{M}$ tryptophan and $95 \mathrm{mM} \mathrm{H}_{2} \mathrm{SO}_{4}$. Quenched reactions were diluted 1:1 in P1 nuclease buffer (250 mM sodium acetate, $\mathrm{pH}$ 6.0, $45 \mathrm{mM} \mathrm{NaCl}, 4$ $\mathrm{mM} \mathrm{ZnCl} 2)$. Antarctic phosphatase $(10 \mathrm{U})$ and $\mathrm{P} 1$ nuclease $(1 \mathrm{U})$ were added to digest the RNA into individual nucleosides. The digestion reactions were incubated at $37{ }^{\circ} \mathrm{C}$ overnight and subsequently analyzed by liquid chromatography (Agilent 1960/1990) coupled to mass spectrometry (LC-MS) (Agilent 6460 QQQ) (LC-MS). Assay mixtures were separated on an Agilent Extend-C18 column $(4.6 \times 50 \mathrm{~mm})$ equilibrated in a $40 \mathrm{mM}$ ammonium acetate, $5 \%$ $(\mathrm{V} / \mathrm{V})$ methanol (solvent A) / 100\% methanol (solvent B) system using the conditions listed in Table 3 below.

MS detection of products (Figure S2) and assignment of peaks were accomplished as described previously. ${ }^{21}$ Results were analyzed with the MassHunter software package, and quantitative analyses were facilitated by comparison to a standard curve calculated from data acquired from the tryptophan internal standard. Unproductive cleavage of SAM was determined by dividing the number of SAM cleavage events, obtained from the concentration of 5' -dA in LC-MS samples, by the estimated number of methylation events $([\mathrm{m} 8 \mathrm{~A}]+2 \cdot[\mathrm{m} 2,8 \mathrm{~A}])$. Six full-length and four variant Cfr proteins were tested for methylase activity. Assays using $C d \mathrm{Cfr}$ in which the $\mathrm{C}$-terminal domain of $C d \mathrm{Cfr}(\mathrm{Cd}-\mathrm{C})$ was removed (giving $\mathrm{Cd}-\mathrm{N})$ are indicated as such in activity measurement plots $(48 \mu \mathrm{M}$ protein). $\mathrm{Cd}-\mathrm{C}$ was also added back separately at a 1:1 ratio. These samples are renamed $\mathrm{Cd}$ $\mathrm{Fe}$ res (iron-bound $\mathrm{Cd}-\mathrm{C}$ ) or $\mathrm{Cd} \mathrm{Zn}$ res (zinc-bound $\mathrm{Cd}-\mathrm{C}$ ) in plots. All assays were performed at least three times on different days. Figures show the average product concentration for three selected experiments, with an error bar showing the standard deviation in these values. The assay metrics in Table S2 are the average \pm standard deviation over the selected trials.

Time courses for experiments using limiting substrate for $B a, E f$, and $P I C$ frs were initially simulated in KinTek Explorer ${ }^{52}$ with the following model.

$$
\mathrm{E}+\mathrm{RNA} \stackrel{k_{1}}{\rightarrow} \mathrm{EM} \stackrel{k_{2}}{\rightarrow} \mathrm{EP}
$$


In this model, enzyme (E) and substrate (RNA) bind and react to form the first product, m8a (EM). This monomethylated compound can be further converted to $\mathrm{m} 2,8 \mathrm{a}$ (EP), as shown above. Both steps are considered to be irreversible. In initial simulations, we found that the best fit for $k_{1}\left(k_{\text {obs }} \mathrm{m} 8 \mathrm{a}\right)$ falls below a lower limit set by the steady-state turnover rate $(v /[\mathrm{E}])$ determined in subsequent experiments with excess RNA. This discrepancy indicated that the simple kinetic model in (1) is not sufficient. However, in the absence of additional experimental data to constrain the rates of other steps (substrate binding, product release, etc.), we instead fixed $k_{1}$ to the lower limit stated above, obtained from fits of m8a production with excess RNA to a single exponential function (described below). We then used KinTek Explorer to simulate the reaction to obtain the apparent rate constant ( $k_{2}$ or $k_{\text {obs }}$ $\mathrm{m} 2,8 \mathrm{a})$ for the second methylation step. Note that in our model, the rate constant for the second dimethylation reaction includes, in addition to the catalysis step, m8a product release and substrate rebinding steps. The fits we obtained are reasonable but, given these complexities, this $k_{2}$ value should be viewed as a lower limit for the rate of the second methylation reaction. For $B a / E f / P I C f r$, the active enzyme fraction was allowed to vary and fell below $48 \mu \mathrm{M}$ for ideal performance in the simulation. Because the limiting-substrate time course of $C d \mathrm{Cfr}$ and its variants yields little dimethylated product, product vs. time traces were fit to a single exponential function to extract the apparent reaction rate ( $k_{\mathrm{obs}}$ m8a) with equation (2), in which a is the product concentration at completion and $k$ is equivalent to $k_{\mathrm{obs}}$ for m8a formation. We assumed a fully active enzyme pool in this analysis.

$$
[\mathrm{m} 8 \mathrm{a}]=\mathrm{a} \cdot\left(1-\mathrm{e}^{-k \mathrm{t}}\right)
$$

\section{RNA methylation activity assays with excess substrate.}

Activity assays with excess substrate were performed as described above but with $100 \mu \mathrm{M}$ 155mer RNA substrate and $3 \mu \mathrm{M}$ Cfr enzyme. The reaction solutions were prepared in 150 $\mu \mathrm{L}$ total volume with $100 \mathrm{mM}$ sodium EPPS, $\mathrm{pH} 8,10 \mathrm{mM} \mathrm{MgCl}_{2}, 12.5 \%$ ( $\mathrm{v} / \mathrm{v}$ ) glycerol, $250 \mathrm{mM} \mathrm{KCl}, 200 \mu \mathrm{M}$ Flv, $20 \mu \mathrm{M}$ Flx, and $2 \mathrm{mM}$ NADPH. Reactions were initiated by addition of $1 \mathrm{mM}$ SAM. Time courses were analyzed via linear fit to the initial portion of the progression curve for $\mathrm{m} 8 \mathrm{a}$ formation to obtain the initial velocities of the reactions. This approach allowed us to obtain a reaction rate, $v /[\mathrm{E}]$, for each Cfr enzyme and variant (Table S3). A single exponential fit, using equation (2), to the full m8a time course allowed us to obtain the amplitude of each enzymatic reaction. This value reflects the total amount of methylated product generated by each enzyme for the entire experiment. The information was used to determine a total turnover number (TON, Table S3), after division by the initial enzyme concentration $(3 \mu \mathrm{M})$. The goal of the latter analysis was to ascertain whether each enzyme is capable of performing more than one full substrate conversion. 


\section{Spectroscopic analysis of Cfr proteins.}

Reconstituted ${ }^{57} \mathrm{Fe}$ protein samples were transferred to EPR tubes or Mössbauer cups and flash-frozen in liquid nitrogen in an anoxic chamber (Coy Laboratory Products). Mössbauer spectra were recorded on constant acceleration Mössbauer spectrometers (SEE Co., Edina, $\mathrm{MN}$ ) equipped either with a Janis SVT-400 variable-temperature cryostat (weak-field) or a Janis 8TMOSS-OM-12SVT variable-temperature cryostat (strong-field) (Janis, Woburn, MA). All isomer shifts are quoted relative to the centroid of the spectrum of a-iron metal at room temperature. Simulations of Mössbauer spectra were carried out using WMOSS (SEE Co., Edina, MN). Some of the simulations are based on the spin Hamiltonian formalism (see equation below), in which the first term describes the electron Zeeman effect, the second and third terms describe the axial and rhombic zero-field splitting of the total electron spin ground state, the fourth term represents the interaction between the electric field gradient and the nuclear quadrupole moment, the fifth term describes the magnetic hyperfine interactions of the ${ }^{57} \mathrm{Fe}$ nucleus with respect to the total electron spin ground state, and the last term represents the nuclear Zeeman interactions of ${ }^{57} \mathrm{Fe}$. All symbols are conventional. 32 Spectra were calculated in the slow relaxation limit.

$$
\begin{aligned}
& H=\beta S \bullet g \bullet B+\mathrm{D}\left(S_{z}^{2}-\frac{\mathrm{S}(\mathrm{S}+1)}{3}\right)+\mathrm{E}\left(S_{x}^{2}-S_{y}^{2}\right)+\sum_{i} \frac{e Q V_{z z, i}}{4}\left[I_{z, i}^{2}-\frac{\mathrm{I}_{\mathrm{i}}\left(\mathrm{I}_{\mathrm{i}}+1\right)}{3}+\frac{\eta}{3}\left(I_{x, i}^{2}-I_{y, i}^{2}\right)\right]+\sum_{i} S \bullet A_{i} \\
& \bullet I_{i}-\sum_{i} \mathrm{~g}_{\mathrm{n}} \beta_{n} B \bullet I_{i}
\end{aligned}
$$

EPR samples were analyzed on a Bruker ESP 300 spectrometer (Billerica, MA) equipped with an ER $041 \mathrm{MR}$ microwave bridge and an ER 4116DM resonator.

\section{UV-visible spectrophotometry.}

Oxidation of the $C d \mathrm{Cfr} C$-terminal domain was analyzed spectrophotometrically using an Agilent 8453 G1103A spectrometer. In an anoxic glovebox, a $50 \mu \mathrm{L}$ sample of $9.4 \mathrm{mM} \mathrm{Cd}$ $\mathrm{C}$ [10 mM HEPES pH 7.5, $500 \mathrm{mM} \mathrm{KCl,} 5 \mathrm{mM}$ DTT, $10 \mathrm{mM} \mathrm{MgCl}_{2}, 25 \%$ ( $\left.v / v\right)$ glycerol] was diluted to $1 \mathrm{~mL}$ in water and sealed in a screw cap quartz cuvette (Starna Cells, Inc). The anoxic protein solution was scanned from $190 \mathrm{~nm}$ to $1100 \mathrm{~nm}$ with a baseline correction at $800 \mathrm{~nm}$. The sample was oxidized by opening the cuvette and pipetting the sample intermittently to introduce oxygen into the solution. The cuvette remained open for the duration of the experiment. The solution was scanned at the following times: $1 \mathrm{~min}, 2.5 \mathrm{~min}$, $5 \mathrm{~min}, 7.5 \mathrm{~min}, 10 \mathrm{~min}, 20 \mathrm{~min}$, and $30 \mathrm{~min}$. A difference spectrum was calculated by subtracting the initial anoxic spectrum from the final spectrum.

\section{Protein film voltammetry.}

Square-wave (SW) voltammetry experiments were performed on a VersaSTAT 3 (Princeton Applied Research) attached to a three-electrode electrochemical cell housed in an anaerobic chamber (Coy Laboratory Products). Protein films were generated via incubation of $9.4 \mathrm{mM}$ Cd-C [10 mM HEPES pH 7.5, $500 \mathrm{mM} \mathrm{KCl,} 5 \mathrm{mM}$ DTT, $10 \mathrm{mM} \mathrm{MgCl} 2,25 \%$ ( $v / v$ ) glycerol] on a pyrolytic graphite edge (PGE) working electrode for $10 \mathrm{~min}$ at room temperature. The working electrode surface was prepared by polishing the electrode surface 
with $0.3 \mu \mathrm{m}$ alumina slurry (Allied High Tech) followed by washing in nanopure $\mathrm{H}_{2} \mathrm{O}$ in a sonication bath for $6 \mathrm{~min}$. The electrode was dried and brought into the glovebox. All subsequent steps were performed under anoxic conditions. The background current was measured with the bare PGE working electrode, $\mathrm{Ag} / \mathrm{AgCl}$ reference electrode (Pine Research), and Pt wire auxiliary electrode in $50 \mathrm{mM}$ HEPES, pH 7.5, $300 \mathrm{mM} \mathrm{KCl}$. SW voltammograms were collected using a step potential of $10 \mathrm{mV}$, a pulse amplitude of $25 \mathrm{mV}$, and a SW frequency of $10 \mathrm{~Hz}$. A current range gate of $20 \mu \mathrm{A}$ was applied and a $1 \mathrm{kHz}$ filter was used as a background filter. A significant decrease in current amplitude was observed between the first and second scans with smaller decreases evident upon successive scans.

\section{Genome neighborhood network (GNN) and isoelectric point analysis of cysteine-rich KTR proteins.}

The complete FASTA file for the cysteine-rich KTR family was downloaded from Interpro (IPR025957) and used to generate sequence similarity networks (SSNs) with the EFIEST server $^{33}$ via default parameters. An SSN calculated with an alignment score of 31 was used to make a genome neighborhood network with the EFI-GNT server ${ }^{34}( \pm 10$ ORFs, $\geq 5 \%$ cooccurrence). Results were visualized and analyzed in Cytoscape.

To calculate the predicted isoelectric points of cysteine-rich KTRs, the full FASTA file for IPR025957 was pruned with the ExPASy decrease redundancy tool $(<98 \%$ minimum identity), and the resulting FASTA file was used as input to the protein isoelectric point calculator web server (http://isoelectric.org/). ${ }^{35}$ The results for each individual KTR were averaged to obtain the overall predicted isoelectric point for the entire family.

\section{Calculating enzyme abundances from metagenomic analysis.}

The EFI-CGFP/shortBRED webtool was used to determine the abundance of KTRs in metagenomic samples obtained as part of the Human Microbiome Project (HMP). ${ }^{33,36-40}$ The KTR SSN described above (alignment score $=31$ ) was used as the input file for marker identification (UniRef90 database, CD-hit identity $=85$, DIAMOND pairwise comparison algorithm). Marker quantification with USEARCH in 380 healthy microbiome datasets yielded a genome-normalized median protein abundance heatmap. The dataset compares the relative quantity of KTR coding sequences (separated by cluster) per microbial genome at six different body sites. To highlight the relative abundance of radical SAM-adjacent KTR proteins in gut microbiome samples, boxplots for clusters 1-3 were generated in Kaleidagraph using the genome-normalized median protein abundance. The shaded area represents the median quartile $(\mathrm{Q} 2)$, and the error bars extend to the first $(\mathrm{Q} 1)$ and third $(\mathrm{Q} 3)$ quartiles. Data points outside of these quartile limits are plotted as open circles.

\section{RESULTS}

\section{Selection of phylogenetically diverse Cfr candidates for biochemical and biophysical characterization.}

To identify Cfrs of diverse origin for biochemical and biophysical studies, we performed BLAST searches of the NCBI non-redundant protein sequence database using $\mathrm{Sa} \mathrm{Cfr}$ as a query. The resulting set of 361 representative sequences was used to construct a minimum 
evolution phylogenetic tree (Figure 2A) with an unrelated radical SAM class B methylase, $\mathrm{TsrM},{ }^{13}$ as the outgroup. The initial search included two groups of annotated RlmN enzymes that share 37\% sequence identity with $\mathrm{Sa}$ Cfr but belong to distinct sequence clusters. The more distantly branched RlmN group is composed of sequences from Firmicutes and Chloroflexi organisms. The second group includes putative $\mathrm{R} / \mathrm{mN}$ sequences from Candidatus phyla and obligate intracellular parasites. Annotated Cfrs cluster into a eukaryotic group and two different bacterial clades, as described previously. ${ }^{24,}{ }^{41}$ Plasmidencoded Cfrs with validated C8 methylation activity from staphylococcal clinical isolates 9 belong to a group that also includes genomically-encoded Bacillales sequences ${ }^{42}$ and plasmid-encoded Cfr proteins from Enterococcus facaelis (Ef) and other enterococcal pathogens. From the latter group, we selected a $E f$ plasmid-borne $\mathrm{Cfr}$ and a genomic sequence from a mesophilic strain of $B$. amyloliquefaciens $(B a)$ for study here. The similarity ( $75 \%$, Table 1) of these sequences to $S a$ Cfr suggests that the $E f$ and $B a$ proteins are likely to have the same activity, methylation of rRNA at A2503 C8. In support of this hypothesis, several antibiotic-resistant enterococcal clinical isolates have recently been demonstrated to harbor a transposable element with a $\mathrm{Cfr}$ that is $99 \%$ sequence identical to $E f \mathrm{Cfr}$ from strain TX0635 analyzed here. ${ }^{43-46} \mathrm{Cfr}$ homologs from an alternative Ba strain (92\% identity to the Cfr from DSM-7 ATCC 23350 targeted in this work), B. clausii, and B. brevis all confer multidrug antibiotic resistance when expressed heterologously in $E$. coli AS19, a strain with high antibiotic susceptibility. ${ }^{42}$ In the latter systems, the mechanism of drug resistance has been directly linked to methylation of A2503, confirmed in a primer extension analysis of total rRNA from an $r I m N$ knockout of $E$. coli following induction of Bacillales Cfr expression. ${ }^{42}$ In all of these studies, conversion of A2503 to the singly- and di- methylated forms was not confirmed in vitro with purified proteins or analyzed quantitatively.

The second bacterial clade is dominated by genomic sequences from Firmicutes and partitioned into three distinct groups. One of these clusters is composed largely of sequences from the Paenibacillus genus. ${ }^{23}$ It includes a representative [Paenibacillus lautus $s p$. Y412MC10 $(P I)]$ originally isolated from the Obsidian hot spring at Yellowstone National Park. ${ }^{47}$ This $P I C f r$ sequence was selected for characterization, owing to the utility of thermotolerant proteins in structural and biophysical studies. Many of the remaining sequences are found in Clostridial organisms. Some of these proteins have been annotated as Cfr-like and are postulated to be functionally divergent from $\mathrm{Sa} \mathrm{Cfr}^{24}$ Our analysis shows that this subset breaks down into two smaller groups that consist of genomically-encoded Cfrs from a set of pathogenic Clostridium difficile ( $C d$ ) strains, now reclassified to the Clostridioides genus, and a larger group of Cfrs from more diverse clostridial organisms. The second group includes Cfr sequences from $C$. sporogenes and C. phytofermentas recently demonstrated to lack rRNA methylation activity. ${ }^{23,24}$ We purified a Cfr from $C$. sporogenes and validated this finding but further characterization of the enzyme was not feasible owing to low soluble expression in E. coli.

Intriguingly, five members of the $C d \mathrm{Cfr}$ cluster have an extended C-terminal motif (Fig. 1B). A BLAST search of the corresponding amino acid sequence shows similarity to an InterPro family (IPR025957) ${ }^{1}$ designated "cysteine-rich KTR" with more than 1400 members identified as of May 2019. The group was initially named for a common internal 
Arg-Thr-Lys sequence, although among the current set of IPR025957 sequences, this motif is not universally conserved. Members are most often found as stand-alone proteins approximately 60 amino acids in length, with two additional strictly conserved CXXC motifs. To date, none of these proteins has been functionally characterized in purified form. Cys-rich KTRs are found almost exclusively in Firmicutes, most in the order Clostridales (968 annotated genes). A Cfr-KTR fusion sequence from Clostridioides difficile str. QCD-63q $42^{48}$ was selected for in vitro characterization in this study. In evaluating the activity and properties of this fusion enzyme, we sought to understand whether it lacks known Cfr activity upon heterologous production in E. coli, as shown for the C. sporogenes and $C$. phytofermentans homologs. In work by other laboratories, a $C$. difficile $\mathrm{Cfr}$ homolog has been shown to confer antibiotic resistance via A2503 modification, but the activity was promoted by a cfr on a mobile genetic element that shares only $52 \%$ sequence identity with our chromosomally-encoded $C d$ homolog. ${ }^{49}, 50$ A Clostridium boltae Cfr-KTR fusion has also been shown to confer moderate drug resistance in cell-based assays. ${ }^{51}$ Neither of these proteins has been purified and characterized in vitro, however. In our work, we also aim to elucidate the function and properties of the distinctive $\mathrm{C}$-terminal Cys-rich domain in our selected $C d$ enzyme.

\section{Diverse Cfr homologs exhibit RNA methylation activity.}

To test for activity in the new Cfr homologs and probe possible functions of the fused Cysrich domain, we viewed two types of activity measurements as likely to be most informative. We assessed (i) sequential mono- and di-methylation of the relevant adenine in a previously reported 155mer RNA substrate derived from $23 S$ rRNA under conditions of high enzyme concentration and limiting substrate and (ii) catalytic monomethylation of the same base/ substrate under conditions of low enzyme concentration and excess RNA. The RNA substrate is a transcribed 155mer of $23 S$ rRNA substrate (nt 2454-2608) from an Ec rRNA template. $E c$ rRNA has been used to characterize the activity of heterologous Cfr enzymes, both in assays with purified protein/RNA components ${ }^{7}$ and in cells. ${ }^{11}$ We elected to use the same substrate to facilitate comparison to $\mathrm{Sa}$ Cfr enzymes. The sequence identities of these rRNA fragments to the corresponding region of native host organism 23S rRNA range from 87 to $90 \%$ (Figure S1). Reactions were initiated by addition of excess SAM to reaction mixtures containing NADPH and a protein-based $E c$ flavodoxin/flavodoxin reductase (Flv/ Flx) system for reduction of the $[4 \mathrm{Fe}-4 \mathrm{~S}]^{2+}$ cluster of Cfr. ${ }^{52,}{ }^{53} \mathrm{In}$ LC-MS analyses of the digested RNA products in both assays, new peak(s) can be assigned to C8-methyladenosine (m8a) or C2,C8-dimethyl-adenosine ( $\mathrm{m} 2,8 \mathrm{a}$ ) based on retention times, $\mathrm{m} / \mathrm{z}$ values, and MS/MS fragmentation (Figure 3A and Figure S2) ${ }^{6,7}$ Assignment of the methylated adenine products to A2503 was confirmed by comparison to an A2503G RNA substrate in $\mathrm{Ba}$ and $C d$ Cfr assays. The AàG variant yields negligible turnover (Figure S3). Methylation of A2503 by $P I C f r$ was demonstrated in a previous study. ${ }^{23}$

HPLC-MS analysis of the limiting substrate reactions (i) revealed detectable levels of monomethylated and dimethylated products for three of the four enzymes (Figure 3B-D). The quantities of the two products were consistent with sequential reactions. Build-up of the $\mathrm{m} 2,8$ a product initially lagged while the $\mathrm{m} 8$ a product grew in, and the $\mathrm{m} 2,8$ a product then accumulated significantly as the m8a product was depleted (Figure 3B-D). In general, these 
enzymes resemble $\mathrm{SaCfr}$ in their ability to catalyze sequential mono- and dimethylation reactions, albeit with varying efficiencies. The $C d$ homolog is an outlier in that it produced very little of the dimethylated product (Figure 3E).

In the limiting substrate time course, $B a \mathrm{Cfr}$ accumulates the greatest amount of singly and dimethylated product and exhibits the fastest initial rate of catalysis for both reactions (Figure 3B). The kinetic profiles of the $B a, E f$, and $P l$ enzymes were analyzed ${ }^{54}$ to extract $k_{\text {obs }}$ for the first methylation step (Figure S4 and Table S2). The rate $\left(0.23 \mathrm{~min}^{-1}\right)$ and extent of $\mathrm{BaCfr} \mathrm{C} 8$ methylation ( $80 \%$ substrate consumption within $20 \mathrm{~min}$ of initiation) is comparable to previously reported values for $\mathrm{Sa}$ Cfr analyzed under similar (limiting RNA) conditions $\left(0.7 \pm 0.2 \mathrm{~min}^{-1}\right.$ with $>80 \%$ of the substrate consumed within the first $5 \mathrm{~min}$ of the reaction). ${ }^{55} \mathrm{By}$ contrast, the $\mathrm{Pl}$ and $E f$ enzymes exhibit rates of $\mathrm{C} 8$ methylation that are 5- to 10-fold lower (0.07-0.14 $\mathrm{min}^{-1}$ ), while the $C d \mathrm{Cfr}$ reaction proceeds even more slowly $\left(0.02 \mathrm{~min}^{-1}\right)$ (Figure 3E, Table S2). To understand whether uncoupled SAM consumption could account for these differences, we quantitatively analyzed the 5'-dA and SAH byproducts (Table S2). All enzymes exhibited a near 1:1 ratio of SAH:methylated product. Abortive SAM cleavage was assessed by comparing the amount of methylated RNA produced to the 5'-dA coproduct (Figure S5). All of the homologs tested exhibited slightly elevated levels of 5'-dA (1.3-1.7), suggesting modest uncoupling under these conditions. However, the similarities between the enzymes indicate that abortive SAM cleavage cannot account for the differences in initial methylation rate. Nevertheless, the Ba enzyme is the most efficiently coupled with a 1.3:1 ratio of 5'-dA:methylated product. Under limiting substrate conditions, with the exception of $\mathrm{BaCfr}$, none of the enzymes consumed the rRNA substrate completely (Table S2). This outcome could be due to a number of different factors. It may arise from use of a non-native RNA substrate in our assays. It could also reflect a propensity for enzyme inactivation or product inhibition.

In the second type of activity assay (ii), we incubated low concentrations of enzyme ( $3 \mu \mathrm{M})$ with excess RNA substrate $(100 \mu \mathrm{M})$ at room temperature (Figure $4 \mathrm{~A}-\mathrm{D})$. In these reactions, the $\mathrm{m} 2,8 \mathrm{a}$ dimethylated product was barely detectable (Figure S6), implying that none of the Cfr homologs methylate the RNA processively and that the first C8 methylation site is vastly preferred over the second, $\mathrm{C} 2$. The excess substrate assays show that all enzymes exhibit the capacity to undergo more than one m8 methylation event, with 2-14 conversions observed within the $\sim 3 \mathrm{~h}$ assay window (Table S3). All are appreciably slower than $\mathrm{SaCfr}(0.24$ $\pm 0.06 \mathrm{~min}^{-1}$ when assayed under similar multi-turnover conditions $)^{19}$ with the exception of $B a \mathrm{Cfr}\left(\mathrm{v} /[\mathrm{E}]=0.23 \mathrm{~min}^{-1}\right)$ (Figure S6, Table S3). The $C d$ enzyme is the slowest catalyst in this assay, with an $\mathrm{m} 8$ methylation rate $(\mathrm{v} /[\mathrm{E}])$ that is $5-30 \%$ that of the other homologs and the lowest level ( 5\%) of total RNA substrate consumption. In $C d \mathrm{Cfr}$, we also considered that the low rate of in vitro turnover with excess substrate could be linked to the presence of the extra C-terminal domain. To address this question, we characterized the function and properties of this domain and analyzed the activity of truncated variants.

\section{Spectroscopic analysis of Cfrs reveals an additional iron-binding site in $\mathrm{Cd}$ Cfr.}

In order to verify the [4Fe4S] cluster content and interrogate the capacity of the $C d$ Cfr Cterminal domain to bind iron, we examined Cfr homologs by Mössbauer spectroscopy 
(Figure 5). Spectra from $B a, E f$, and $P I C f r$ are dominated by a single quadrupole doublet with parameters consistent with $[4 \mathrm{Fe} 4 \mathrm{~S}]^{2+}$ clusters $\left(\delta=0.44-0.45 \mathrm{~mm} / \mathrm{s}\right.$ and $\Delta \mathrm{E}_{\mathrm{Q}}=1.11$ $\mathrm{mm} / \mathrm{s}$ in each case). ${ }^{56}$ From the relative area of the subspectrum associated with $[4 \mathrm{Fe}-4 \mathrm{~S}]^{2+}$ clusters and the amount of $\mathrm{Fe} /$ protein after reconstitution, the number of clusters per protein can be estimated. ${ }^{30}$ After reconstitution, Ba, Ef, and PICfr contain 4.6, 4.2, and 3.9 Fe per protein, corresponding to $1.1,1.0$, and $0.9[4 \mathrm{Fe} 4 \mathrm{~S}]^{2+}$ clusters per protein, respectively (Table 2). In addition to the features of a $[4 \mathrm{Fe} 4 \mathrm{~S}]$ cluster $\left(\delta=0.45 \mathrm{~mm} / \mathrm{s}\right.$ and $\left.\Delta \mathrm{E}_{\mathrm{Q}}=1.14 \mathrm{~mm} / \mathrm{s}\right)$, the Mössbauer spectrum of $C d \mathrm{Cfr}$ contains a second quadrupole doublet feature with parameters $\left(\delta=0.70 \mathrm{~mm} / \mathrm{s}\right.$ and $\left.\Delta \mathrm{E}_{\mathrm{Q}}=3.08 \mathrm{~mm} / \mathrm{s}\right)$, similar to those of a $\mathrm{Fe}^{2+}$-Cys $_{4}$ rubredoxin center. ${ }^{56}$ We propose that this $\mathrm{Fe}^{2+}$ center is coordinated by the four conserved cysteine residues in the C-terminal KTR region of the protein (vide supra). Analysis of all four Cfrs by electron paramagnetic resonance spectroscopy did not result in any detectable signals for the as-isolated reconstituted proteins, thus ruling out assembly of any iron-sulfur clusters with an $S=1 / 2$ ground state in these samples.

To test the hypothesis that the $[4 \mathrm{Fe} 4 \mathrm{~S}]^{2+}$ cluster and rubredoxin-like center in $\mathrm{Cd}$ Cfr reside in the $\mathrm{N}$-terminal and $\mathrm{C}$-terminal domains, respectively, $\mathrm{N}$-terminal (residues 1-345, Cd-N) and C-terminal (residues 346-416, Cd-C) fragments of $C d \mathrm{Cfr}$ were produced. Mössbauer spectra of these truncated proteins (Figure 5) unambiguously demonstrate that the [4Fe4S] cluster resides in the $\mathrm{N}$-terminal radical SAM domain, whereas the ferrous rubredoxin-like center resides in the C-terminal cysteine-rich KTR domain. In order to gain additional insight into the electronic structure of the rubredoxin-like species in $C d \mathrm{Cfr}$, we examined Cd-C using Mössbauer spectroscopy at $4.2 \mathrm{~K}$ in variable externally applied magnetic fields (Figure 5). The spectra can be simulated with the following parameters and assuming a $S=2$ electron spin ground state: $D=5.7 \mathrm{~cm}^{-1}, E / D=0.2, \delta=0.70 \mathrm{~mm} / \mathrm{s}, \Delta \mathrm{E}_{\mathrm{Q}}=3.08 \mathrm{~mm} / \mathrm{s}, \eta=$ 0.9 , and $\mathbf{A} / \mathrm{g}_{\mathrm{N}} \beta_{\mathrm{N}}=[-14.4,-8.3,-23.3] \mathrm{T}$, similar to those previously reported for ferrous rubredoxin centers coordinated by four cysteines. 56,57

\section{The $C d$ Cfr C-terminal domain is not essential for RNA methylation activity but functions less efficiently in the absence of $\mathrm{Fe}^{2+}$.}

The truncated version of $C d \mathrm{Cfr}, C d-\mathrm{N}$, lacking the $\mathrm{C}$-terminal Cys-rich domain, is as efficient in m8a production as full-length $C d$ Cfr in experiments using the Flv/Flx/NADPH reducing system with limiting RNA (Figure 6A-B, Figure S7A). Attempts to modulate activity by addition of the isolated $\mathrm{Fe}^{2+}$-loaded $\mathrm{C}$-terminal domain in trans ( $C d \mathrm{Fe}$ res) did not yield any significant difference in product formation. To investigate the functional role of the $\mathrm{Fe}^{2+}$ center in the $\mathrm{Cd}$ Cfr C-terminal domain, a variant of one of the putative metalbinding residues in the CXXC motif, a Cys363 $\rightarrow$ Ala substitution (C363A, renamed Cd $\mathrm{M}$ ), was generated in the full-length enzyme. Unexpectedly, this substitution alters ironsulfur cluster stability, giving a sample with $<3$ equiv Fe/protein after reconstitution, as determined by ICP-OES analysis. Similar cluster instability is precedented in $[4 \mathrm{Fe} 4 \mathrm{~S}]^{2+}$ DNA repair enzymes upon mutation of an auxiliary metal binding site Cys ligand. ${ }^{58,59}$ As a consequence, the $\mathrm{C} 363 \mathrm{~A} C d \mathrm{Cfr}$ enzyme exhibits negligible activity. A $\mathrm{Zn}^{2+}$-loaded version of the C-terminal domain was also tested ( $\mathrm{Cd} \mathrm{Zn}$ res) for rescue of RNA methylation activity. Inclusion of the mismetallated $\mathrm{Cd}-\mathrm{C}$ domain gives a slight decrease in activity in limiting substrate assays (Figure 6B, Figure S7A). We also evaluated the activity of variant 
forms of $C d$ Cfr with excess RNA ( $3 \mu \mathrm{M}$ enzyme, $100 \mu \mathrm{M}$ 155mer rRNA) (Figure 6C). The trends observed in the limiting substrate assays are largely maintained, with little effect on endpoint product formation upon truncation of $C d$ Cfr. However, at early time points, a detectable lag in product formation is evident in the rescue experiment (Figure S8). Interestingly, the impact of $\mathrm{Zn}^{2+}$-substitution in the $\mathrm{C}$-terminal domain is magnified with excess substrate. We observe only a small amount of product after $2.75 \mathrm{~h}$ (Figure 6C, Figure S7B), underscoring the initial findings from single turnover assays. Disruption of the Cterminal domain iron-binding site via ligand mutation or metal ion substitution impedes turnover.

\section{The isolated $C d$ Cfr $\mathrm{C}$-terminal domain exhibits rubredoxin-like redox properties.}

Although our activity assays do not indicate an essential role in in vitro catalysis for the metal-bound $\mathrm{C}$-terminal domain in $C d \mathrm{Cfr}$, particularly under limiting substrate conditions, we speculated that the domain could mediate electron transfer (ET) steps in the rRNA methylation reaction. This function may be dispensable with a non-native reductant in vitro but more critical in vivo (e.g., with a clostridial protein-based redox donor). Our Mössbauer experiments revealed a Rdx-type $\mathrm{Cys}_{4}$-coordinated $\mathrm{Fe}^{2+}$ center in the version of this protein isolated from an $E$. coli heterologous host and expressed under iron-replete conditions in minimal medium. Given that Rdx proteins typically serve as high-potential electron-transfer shuttles that operate by cycling between $\mathrm{Fe}^{2+}$ and $\mathrm{Fe}^{3+}$ oxidation states, ${ }^{60}$ we sought to characterize the redox properties of as-isolated $\mathrm{Cd}-\mathrm{C}$. Anaerobic isolation of $\mathrm{Cd}-\mathrm{C}$ yields a clear/bluish protein solution that is exclusively $\mathrm{Fe}^{2+}$ by Mössbauer analysis. Exposure of the domain to $\mathrm{O}_{2}$ results in a visible color change to a red solution that, when monitored spectrophotometrically, exhibits absorption bands at 370, 485, and $582 \mathrm{~nm}$ (Figure 7A). These spectral features resemble those of oxidized stand-alone Rdx proteins. ${ }^{61}$

Previously characterized Rdx proteins also exhibit reduction potentials in the -50 to $+50 \mathrm{mV}$ range (vs. NHE) ${ }^{60}$ To measure the $\mathrm{Fe}^{2+/ 3+}$ midpoint potential of the isolated $\mathrm{Cd}-\mathrm{C}$ domain, protein films were generated on pyrolytic edge graphite (PGE) electrodes under anaerobic conditions by incubation of protein [9.4 mM in $10 \mathrm{mM}$ HEPES pH 7.5, $500 \mathrm{mM} \mathrm{KCl}, 5 \mathrm{mM}$ DTT, $10 \mathrm{mM} \mathrm{MgCl} 2,25 \%$ ( $v / v)$ glycerol] on the electrode surface for $10 \mathrm{~min}$. Modified electrodes were transferred to an electrochemical cell (50 mM HEPES, pH 7.5, and $300 \mathrm{mM}$ $\mathrm{KCl}$ buffer), and evaluated by square-wave (SW) voltammetry. Voltammograms obtained at a SW frequency of $10 \mathrm{~Hz}$ showed a quasi-reversible waveform with a midpoint potential of $+106 \mathrm{mV}$ vs. NHE (Figure 7B). The relatively high midpoint potential compared to prototypical Rdx proteins can be rationalized by differences in the predicted charge of $\mathrm{Cd}-\mathrm{C}$ at $\mathrm{pH}$ 7.5. Cd-C has a calculated $\mathrm{pI}$ of 9.2, compared to 4.0 for a canonical Rdx. At physiological $\mathrm{pH}, \mathrm{Rdx}$ would be largely negative while $\mathrm{Cd}-\mathrm{C}$ would have a net positive charge. This scenario would destabilize the $\mathrm{Fe}^{3+}$ state in $\mathrm{Cd}-\mathrm{C}$, rendering the protein more difficult to oxidize and resulting in a higher midpoint potential. Interestingly, subsequent electrochemical scans of the isolated domain show loss of current amplitude over time, suggesting that the domain may not be stable in the oxidized form. In the presence of $\mathrm{O}_{2}$, $\mathrm{Cd}-\mathrm{C}$ visibly precipitated over the $30 \mathrm{~min}$ time period in which the protein was monitored electrochemically. These observations could preclude a role for the $\mathrm{Fe}^{2+}$ center as an explicit electron donor in Cfr catalysis. However, the stability/reduction potential may be further 
modulated via interaction with the radical SAM domain of $C d$ Cfr and/or the RNA substrate. The protein could also require binding to the protein reducing system prior to ET to ensure rapid re-reduction to the $\mathrm{Fe}^{2+}$ oxidation state.

\section{Homologs of the $\mathrm{Cd} \mathrm{C}$-terminal domain are widespread as stand-alone proteins in Clostridiales.}

Spectroscopic and electrochemical analyses of the isolated $C d$ Cfr C-terminal domain suggest properties similar to Rdx ET proteins. Although traditional Rdx proteins are similar in length ( $\sim 60$ aa) and contain identical CXXC metal binding motifs separated by $\sim 20-30$ amino acids, the overall sequence identity between the $\mathrm{Cd}-\mathrm{C}$ domain and a model $\mathrm{Rdx}$ from C. pasteurianum is only 30\% (Figure 7D). $C p \mathrm{Rdx}$ (and other $\mathrm{Rdx}$ proteins with validated function/properties) additionally contain a conserved Gly immediately adjacent to the Cterminal Cys in each metal binding motif. This sequence pattern enables key H-bonds to form between peptide backbone $\mathrm{N}-\mathrm{H}$ groups and the metal-coordinated thiolates of Cys residues. These interactions can influence $\mathrm{Rdx}$ reduction potential. ${ }^{62}$ Interestingly, Cd-C deviates from this sequence pattern significantly because it contains a Lys residue immediately adjacent to each CXXC motif. In general, $\mathrm{Cd}-\mathrm{C}$ has a high proportion of positively charged residues, accounting for its aforementioned $\mathrm{pI}>9$, while $C p \mathrm{Rdx}$ has a net negative charge at neutral $\mathrm{pH}$. These observations leave open the possibility that while Cd-C functionally resembles Rdx proteins, it may adopt a distinct structure.

Our initial identification of the $\mathrm{Cd}-\mathrm{C} \mathrm{Fe} \mathrm{F}^{2+}$-binding domain via sequence inspection revealed homology to a large group of bacterial stand-alone proteins annotated as Cys-rich KTR proteins. The latter naming scheme comes from an Arg-Thr-Lys sequence that resides in between the two strictly conserved CXXC motifs. Additionally, analysis of the Cys-rich KTR sequence group shows that the stand-alone proteins are also dominated by positively charged residues, resulting in an average isoelectric point of 8.6. Our discovery of an essential $\mathrm{Fe}^{2+}$ binding site in the Cfr-fused version of this domain raises the possibility that the larger family of stand-alone Cys-rich KTR proteins might have the same property, with widespread functional significance for the metal-bound form. To gain insight into this possibility, we analyzed patterns in genome neighbors ( \pm 10 open reading frames) for the entire InterPro family. ${ }^{33}$ The resulting sequence similarity network revealed that $13 \%$ of the Cys-rich KTR family can be found in two large clusters (133 sequences, clusters 1 and 3 in Fig. 8A). For the 85 of the 133 sequences from organisms with fully sequenced genomes, 84 are encoded directly adjacent to a putative RNA methylase. As in the $\mathrm{Cd}$ Cfr fusion enzyme studied here, nearly all of these Cys-rich KTRs are from organisms belonging to the clostridiales order (Table S4). This subset of Cys-rich KTR proteins may function similarly to $\mathrm{Cd}-\mathrm{C}$, sharing its requirement for $\mathrm{Fe}^{2+}$ and exhibiting $\mathrm{Rdx}$-type redox properties. Interestingly, the organisms with paired Cfr-KTR gene clusters identified in this analysis are commonly found as commensal human gut microbiome constituents (Table S4). We further validated this observation by analyzing the healthy human microbiome metagenome abundance of Cys-rich KTR genes via the Enzyme Function Initiative chemically-guided functional profiling (CGFP) web tool (Figure 9). ${ }^{35-37}$ The KTR genes associated with clusters 1 and 3 are significantly enriched in human stool microbiome metagenomes. These 
patterns could indicate a reservoir of Cys-rich KTR-Cfr genes in the beneficial gut flora to protect against antibiotic exposure with the possibility of transfer to pathogens.

\section{DISCUSSION}

In this study, we establish that four different Cfr enzymes from distinct phylogenetic groups assemble a necessary $[4 \mathrm{Fe} 4 \mathrm{~S}]^{2+}$ cofactor and exhibit adenine C8 RNA methylation activity in vitro, similar to the well-characterized Cfr homolog from $S$. aureus. Under the assay conditions tested, three of the four enzymes analyzed exhibit both mono- and di-methylation activity. We also show that a genomically encoded Cfr from a Bacillales organism consumes substrate at a comparable rate to $\mathrm{Sa} \mathrm{Cfr}$ with both limiting and excess RNA. These results establish that diverse $\mathrm{Cfr}$ homologs are viable targets for structural and biophysical study.

In vitro characterization of a clostridial Cfr homolog fused to a Cys-rich C-terminal domain also reveals an active mono-methylase with limiting substrate. However, with a $>30$-fold excess of RNA substrate, the clostridial fusion enzyme is markedly less active. Combined with the unexpected detection of a rubredoxin-like $\mathrm{Fe}^{2+}$ binding site in the $\mathrm{C}$-terminal domain of $\mathrm{Cd} \mathrm{Cfr}$, these findings prompted a more detailed investigation of the properties of this module. Complete removal of the domain fails to either increase or decrease the rate of RNA methylation in reactions initiated by a protein-based reducing system, but disruption of the $\mathrm{Fe}^{2+}$ binding site by ligand mutagenesis or $\mathrm{Zn}^{2+}$ substitution decreases turnover. While the effect of $\mathrm{Zn}^{2+}$ is modest with limiting substrate, the mismetallated enzyme is nearly inactive when challenged with excess RNA. Our spectroscopic and electrochemical analysis of the stand-alone domain suggests a similarity to rubredoxin-type electron transfer cofactors, often described as a particularly minimalist member of the iron-sulfur cluster cofactor family.

Many radical SAM enzymes harbor additional iron-sulfur clusters with diverse functions, including electron transfer. ${ }^{63,64}$ The redox-neutral carbon methylation catalyzed by $\mathrm{R} l \mathrm{mN} / \mathrm{Cfr}$ enzymes shares in common with other radical SAM-mediated C-C bond forming systems a requirement for reductive quenching of a substrate radical at the end of the reaction. ${ }^{12}$ In other superfamily members, auxiliary cofactors or redox-active amino acids in the active site can mediate controlled provision of redox equivalents. ${ }^{65,} 66 \mathrm{In} \mathrm{Cfr}$ and RlmN, a conserved C-terminal Cys residue is oxidized to a thiyl radical to facilitate product release (Figure 1). ${ }^{14,18}$ The midpoint potential of the $\mathrm{Fe}^{2+}$ cofactor in the $\mathrm{Cd}$ Cfr C-terminal rubredoxin-like domain could enable its use as an electron donor to regenerate the Cys 355 thiolate for subsequent methylation. ${ }^{12}$ We note, however, that the domain is not universally conserved as a Cfr neighbor. Therefore, a KTR-rubredoxin cannot be the sole mechanism of C355 reduction and other means to quench the radical must exist in other Cfr/RlmNs.

Diversity in reductant usage has precedent in other oxidoreductase enzymes. For example, class III ribonucleotide reductases have adapted to use either protein-based (thioredoxin or ferredoxin) or small molecule (formate) reducing systems to resolve an oxidized active site Cys disulfide or a thiosulfuranyl radical. ${ }^{67-69}$ Also, we cannot rule out other roles for the KTR-rubredoxin such as RNA-binding or structural stabilization. However, our work shows that the $\mathrm{Cd}-\mathrm{N}$ truncated protein is stable and active in the absence of the $\mathrm{C}$-terminal domain in vitro. 
The $\mathrm{Cd}$ Cfr rubredoxin-like domain may also serve as an intermediary or coordinator of $\mathrm{Cfr}$ reaction initiation via interaction with protein reducing partners. The reduction potential of the Cd-C domain is likely too high $(+100 \mathrm{mV}$ vs NHE) to donate an electron to the $[4 \mathrm{Fe} 4 \mathrm{~S}]^{2+}$ radical SAM cluster directly, even though a similar role was recently proposed for a stand-alone CSL-family Zn finger protein, Dph3, encoded adjacent to a non-canonical radical SAM enzyme, diphthamide biosynthesis protein Dph2. ${ }^{70,71} \mathrm{Dph} 3$ is the only other example of a biochemically characterized mononuclear metal binding protein found as a genome neighbor to a radical SAM enzyme. The $\mathrm{Fe}^{2+}$-bound form of $\mathrm{Dph} 3$ was reported to function in iron-sulfur cluster reduction in Dph2, initiating the reaction in the absence of reductant. However, the redox potential of Dph3 has not been experimentally determined, and no known rubredoxin-type electron transfer protein has a sufficiently low reduction potential $(<-400 \mathrm{mV})$ for activation of a radical SAM [4Fe4S] cluster. $^{72}$

Our findings also raise the possibility that reported inactivity in RNA methylation in heterologously expressed Cfrs from clostridial clades could be due to lack of a necessary accessory factor or redox partner. The Cys-rich KTR domain is a candidate for such a factor, although this protein is not essential for activity in $C d \mathrm{Cfr}$ and it is not found universally adjacent to the inactive clostridial enzymes. Genome analysis of the remainder of the clostridial Cfr subgroup reveals a second conserved neighbor, an Lsa ABC-F ribosomal protection protein. Our query shows $100 \%$ co-occurrence of clostridial $c$ fr genes with either a KTR or an Lsa neighbor. Lsa has not been structurally characterized in complex with rRNA, but another ABC-F protein, VmlR, binds to the fully-assembled $70 S$ ribosome to prompt a structural change that drives drug release from the peptidyl transferase center. ${ }^{73}$ While $S a$-type Cfrs methylate A2503 solely in a protein-free $23 S$ rRNA context, ${ }^{5}$ clostridial Cfrs could instead modify fully assembled $70 S$ ribosomal rRNA following Lsa remodeling. Such an approach would be particularly efficient, eliminating the fitness cost of preemptively methylating nascent ribosomes.

The genome context of other Cys-rich KTR orthologs suggests the protein may additionally play a more generic role in nucleic acid binding or antibiotic resistance. Apart from the clostridial Cys-rich KTR group found adjacent to Cfr radical SAM enzymes, the second most frequent gene neighbor is TetM, a ribosomal protection protein that confers antibiotic resistance by triggering a conformational change in the tetracycline binding site to release the drug. ${ }^{74}$ Interestingly, this group of KTR homologs is almost exclusively associated with known bacterial pathogens originating from Clostridiales and Bacillales. The remaining KTR proteins are often found near drug efflux systems, with the majority annotated as ABC family transporters or MATE/MFS effluxers. All Cys-rich KTR genes are proximal to transposable elements including helix-turn-helix proteins (HTH3/HTH16), RNA polymerase $\sigma^{70}$ components, and TetR-like repressors. ${ }^{75}$ These patterns suggest KTRs are transferable elements, consistent with a general role in antibiotic resistance. In the other GNN clusters, a functional role for $\mathrm{Fe}^{2+}$ and Rdx-like activity is not immediately evident, although it is interesting to note that the protein families listed above all exhibit some overlap with the biological function of Cfr in drug resistance. The prevalence of Cys-rich KTR genes in pathogens and in members of the human microbiome warrants further investigation of their biological function and metal ion requirements. 


\section{Supplementary Material}

Refer to Web version on PubMed Central for supplementary material.

\section{ACKNOWLEDGEMENTS}

This work was funded by the National Institutes of Health (GM10011 and GM119707 to A.K.B. and GM122595 to S.J.B.) and the National Science Foundation (Grant No. DGE1255832 to R.J.M.) We thank Erica Schwalm for technical assistance/provision of reagents and J. Martin Bollinger Jr. for assistance with data analysis and critical reading of the manuscript. We also acknowledge the resources of the EFI-CGFP and thank Lauren Rajakovich for assistance with metagenome abundance data analysis.

\section{REFERENCES}

[1]. Finn RD, Attwood TK, Babbitt PC, Bateman A, Bork P, Bridge AJ, Chang HY, Dosztanyi Z, ElGebali S, Fraser M, Gough J, Haft D, Holliday GL, Huang H, Huang X, Letunic I, Lopez R, Lu S, Marchler-Bauer A, Mi H, Mistry J, Natale DA, Necci M, Nuka G, Orengo CA, Park Y, Pesseat S, Piovesan D, Potter SC, Rawlings ND, Redaschi N, Richardson L, Rivoire C, Sangrador-Vegas A, Sigrist C, Sillitoe I, Smithers B, Squizzato S, Sutton G, Thanki N, Thomas PD, Tosatto SC, Wu CH, Xenarios I, Yeh LS, Young SY, and Mitchell AL (2017) InterPro in 2017-beyond protein family and domain annotations, Nucleic Acids Res 45, D190-D199. [PubMed: 27899635]

[2]. Frey PA, Hegeman AD, and Ruzicka FJ (2008) The radical SAM superfamily, Crit Rev Biochem Mol Biol 43, 63-88. [PubMed: 18307109]

[3]. Broderick JB, Duffus BR, Duschene KS, and Shepard EM (2014) Radical S-adenosylmethionine enzymes, Chem Rev 114, 4229-4317. [PubMed: 24476342]

[4]. Landgraf BJ, McCarthy EL, and Booker SJ (2016) Radical S-adenosylmethionine enzymes in human health and disease, Annu Rev Biochem 85, 485-514. [PubMed: 27145839]

[5]. Kimura S, and Suzuki T (2015) Iron-sulfur proteins responsible for RNA modifications, Biochim Biophys Acta 1853, 1272-1283. [PubMed: 25533083]

[6]. Yan F, LaMarre JM, Röhrich R, Wiesner J, Jomaa H, Mankin AS, and Fujimori DG (2010) RlmN and Cfr are radical SAM enzymes involved in methylation of ribosomal RNA, J Am Chem Soc 132, 3953-3964. [PubMed: 20184321]

[7]. Grove TL, Benner JS, Radle MI, Ahlum JH, Landgraf BJ, Krebs C, and Booker SJ (2011) A radically different mechanism for $S$-adenosylmethionine-dependent methyltransferases, Science 332, 604-607. [PubMed: 21415317]

[8]. Bauerle MR, Schwalm EL, and Booker SJ (2015) Mechanistic diversity of radical Sadenosylmethionine (SAM)-dependent methylation, J Biol Chem 290, 3995-4002. [PubMed: 25477520]

[9]. Kehrenberg C, Schwarz S, Jacobsen L, Hansen LH, and Vester B (2005) A new mechanism for chloramphenicol, florfenicol and clindamycin resistance: methylation of $23 \mathrm{~S}$ ribosomal RNA at A2503, Mol Microbiol 57, 1064-1073. [PubMed: 16091044]

[10]. Benítez-Páez A, Villarroya M, and Eugenia Armengod M (2012) The Escherichia coli RlmN methyltransferase is a dual-specificity enzyme that modifies both rRNA and tRNA and controls translational accuracy, RNA 18, 1783-1795. [PubMed: 22891362]

[11]. Long KS, Poehlsgaard J, Kehrenberg C, Schwarz S, and Vester B (2006) The Cfr rRNA methyltransferase confers resistance to phenicols, lincosamides, oxazolidinones, pleuromutilins, and streptogramin A antibiotics, Antimicrob Agents Chemother 50, 2500-2505. [PubMed: 16801432]

[12]. Yokoyama K, and Lilla EA (2018) C-C bond forming radical SAM enzymes involved in the construction of carbon skeletons of cofactors and natural products, Nat Prod Rep 35, 660-694. [PubMed: 29633774]

[13]. Blaszczyk AJ, Silakov A, Zhang B, Maiocco SJ, Lanz ND, Kelly WL, Elliott SJ, Krebs C, and Booker SJ (2016) Spectroscopic and Electrochemical Characterization of the Iron-Sulfur and Cobalamin Cofactors of TsrM, an Unusual Radical $S$-Adenosylmethionine Methylase, J Am Chem Soc 138, 3416-3426. [PubMed: 26841310] 
[14]. Silakov A, Grove TL, Radle MI, Bauerle MR, Green MT, Rosenzweig AC, Boal AK, and Booker SJ (2014) Characterization of a cross-linked protein-nucleic acid substrate radical in the reaction catalyzed by RlmN, J Am Chem Soc 136, 8221-8228. [PubMed: 24806349]

[15]. Yan F, and Fujimori DG (2011) RNA methylation by radical SAM enzymes RlmN and Cfr proceeds via methylene transfer and hydride shift, Proc Natl Acad Sci U S A 108, 3930-3934. [PubMed: 21368151]

[16]. Broderick WE, Hoffman BM, and Broderick JB (2018) Mechanism of radical initiation in the radical S-adenosyl-L-methionine superfamily, Acc Chem Res 51, 2611-2619. [PubMed: 30346729]

[17]. Grove TL, Livada J, Schwalm EL, Green MT, Booker SJ, and Silakov A (2013) A substrate radical intermediate in catalysis by the antibiotic resistance protein Cfr, Nat. Chem. Biol 9, 422427. [PubMed: 23644479]

[18]. Schwalm EL, Grove TL, Booker SJ, and Boal AK (2016) Crystallographic capture of a radical Sadenosylmethionine enzyme in the act of modifying tRNA, Science 352, 309-312. [PubMed: 27081063]

[19]. Bauerle MR, Grove TL, and Booker SJ (2018) Investigation of Solvent Hydron Exchange in the Reaction Catalyzed by the Antibiotic Resistance Protein Cfr, Biochemistry 57, 4431-4439. [PubMed: 29787246]

[20]. Ruszczycky MW, Zhong A, and Liu HW (2018) Following the electrons: peculiarities in the catalytic cycles of radical SAM enzymes, Nat Prod Rep 35, 615-621. [PubMed: 29485151]

[21]. Grove TL, Radle MI, Krebs C, and Booker SJ (2011) Cfr and RlmN contain a single [4Fe-4S] cluster, which directs two distinct reactivities for $S$-adenosylmethionine: methyl transfer by SN2 displacement and radical generation, J Am Chem Soc 133, 19586-19589. [PubMed: 21916495]

[22]. Boal AK, Grove TL, McLaughlin MI, Yennawar NH, Booker SJ, and Rosenzweig AC (2011) Structural basis for methyl transfer by a radical SAM enzyme, Science 332, 1089-1092. [PubMed: 21527678]

[23]. Atkinson GC, Hansen LH, Tenson T, Rasmussen A, Kirpekar F, and Vester B (2013) Distinction between the Cfr methyltransferase conferring antibiotic resistance and the housekeeping RlmN methyltransferase, Antimicrob Agents Chemother 57, 4019-4026. [PubMed: 23752511]

[24]. Stojkovic V, Noda-Garcia L, Tawfik DS, and Fujimori DG (2016) Antibiotic resistance evolved via inactivation of a ribosomal RNA methylating enzyme, Nucleic Acids Res 44, 8897-8907. [PubMed: 27496281]

[25]. Edgar RC (2004) MUSCLE: a multiple sequence alignment method with reduced time and space complexity, BMC Bioinformatics 5, 113. [PubMed: 15318951]

[26]. Artimo P, Jonnalagedda M, Arnold K, Baratin D, Csardi G, de Castro E, Duvaud S, Flegel V, Fortier A, Gasteiger E, Grosdidier A, Hernandez C, Ioannidis V, Kuznetsov D, Liechti R, Moretti S, Mostaguir K, Redaschi N, Rossier G, Xenarios I, and Stockinger H (2012) ExPASy: SIB bioinformatics resource portal, Nucleic Acids Res 40, W597-603. [PubMed: 22661580]

[27]. Kumar S, Stecher G, and Tamura K (2016) MEGA7: Molecular Evolutionary Genetics Analysis Version 7.0 for Bigger Datasets, Mol Biol Evol 33, 1870-1874. [PubMed: 27004904]

[28]. Gibson DG (2011) Enzymatic assembly of overlapping DNA fragments, Methods Enzymol 498, 349-361. [PubMed: 21601685]

[29]. Frazzon J, and Dean DR (2003) Formation of iron-sulfur clusters in bacteria: an emerging field in bioinorganic chemistry, Curr Opin Chem Biol 7, 166-173. [PubMed: 12714048]

[30]. Lanz ND, Grove TL, Gogonea CB, Lee KH, Krebs C, and Booker SJ (2012) RlmN and AtsB as models for the overproduction and characterization of radical SAM proteins, Methods Enzymol 516, 125-152. [PubMed: 23034227]

[31]. Stookey LL (1970) Ferrozine — a new spectrophotometric reagent for iron, Anal Chem 42, 779_ 781.

[32]. Münck E (2000) Physical methods in bioinorganic chemistry: spectroscopy and magnetism, University Science Books, Sausalito, CA.

[33]. Gerlt JA, Bouvier JT, Davidson DB, Imker HJ, Sadkhin B, Slater DR, and Whalen KL (2015) Enzyme Function Initiative-Enzyme Similarity Tool (EFI-EST): A web tool for generating 
protein sequence similarity networks, Biochim Biophys Acta 1854, 1019-1037. [PubMed: 25900361]

[34]. Zhao S, Kumar R, Sakai A, Vetting MW, Wood BM, Brown S, Bonanno JB, Hillerich BS, Seidel RD, Babbitt PC, Almo SC, Sweedler JV, Gerlt JA, Cronan JE, and Jacobson MP (2013) Discovery of new enzymes and metabolic pathways by using structure and genome context, Nature 502, 698-702. [PubMed: 24056934]

[35]. Kozlowski LP (2016) IPC - Isoelectric Point Calculator, Biology Direct 11.

[36]. Human Microbiome Project C (2012) A framework for human microbiome research, Nature 486, 215-221. [PubMed: 22699610]

[37]. Human Microbiome Project C (2012) Structure, function and diversity of the healthy human microbiome, Nature 486, 207-214. [PubMed: 22699609]

[38]. Zallot R, Oberg NO, and Gerlt JA (2018) 'Democratized' genomic enzymology web tools for functional assignment, Current Opinion in Chemical Biology 47, 77-85. [PubMed: 30268904]

[39]. Levin BJ, Huang YY, Peck SC, Wei Y, Martinez-Del Campo A, Marks JA, Franzosa EA, Huttenhower C, and Balskus EP (2017) A prominent glycyl radical enzyme in human gut microbiomes metabolizes trans-4-hydroxy-l-proline, Science 355.

[40]. Kaminski J, Gibson MK, Franzosa EA, Segata N, Dantas G, and Huttenhower C (2015) HighSpecificity Targeted Functional Profiling in Microbial Communities with ShortBRED, PLoS Comput Biol 11, e1004557. [PubMed: 26682918]

[41]. Kaminska KH, Purta E, Hansen LH, Bujnicki JM, Vester B, and Long KS (2010) Insights into the structure, function and evolution of the radical-SAM 23S rRNA methyltransferase Cfr that confers antibiotic resistance in bacteria, Nucleic Acids Res 38, 1652-1663. [PubMed: 20007606]

[42]. Hansen LH, Planellas MH, Long KS, and Vester B (2012) The order Bacillales hosts functional homologs of the worrisome cfr antibiotic resistance gene, Antimicrob Agents Chemother 56, 3563-3567. [PubMed: 22547628]

[43]. Deshpande LM, Ashcraft DS, Kahn HP, Pankey G, Jones RN, Farrell DJ, and Mendes RE (2015) Detection of a new $c f r$-Like gene, $c f r(\mathrm{~B})$, in Enterococcus faecium isolates recovered from human specimens in the United States as part of the SENTRY Antimicrobial Surveillance Program, Antimicrob Agents Chemother 59, 6256-6261. [PubMed: 26248384]

[44]. Bender JK, Fleige C, Klare I, Fiedler S, Mischnik A, Mutters NT, Dingle KE, and Werner G (2016) Detection of a cfr(B) Variant in German Enterococcus faecium Clinical Isolates and the Impact on Linezolid Resistance in Enterococcus spp, PLoS One 11, e0167042. [PubMed: 27893790]

[45]. Morroni G, Brenciani A, Antonelli A, D’Andrea MM, Di Pilato V, Fioriti S, Mingoia M, Vignaroli C, Cirioni O, Biavasco F, Varaldo PE, Rossolini GM, and Giovanetti E (2018) Characterization of a Multiresistance Plasmid Carrying the optrA and cfr Resistance Genes From an Enterococcus faecium Clinical Isolate, Front Microbiol 9, 2189. [PubMed: 30271398]

[46]. Kuroda M, Sekizuka T, Matsui H, Suzuki K, Seki H, Saito M, and Hanaki H (2018) Complete Genome Sequence and Characterization of Linezolid-Resistant Enterococcus faecalis Clinical Isolate KUB3006 Carrying a cfr(B)-Transposon on Its Chromosome and optrA-Plasmid, Front Microbiol 9, 2576. [PubMed: 30410481]

[47]. Mead DA, Lucas S, Copeland A, Lapidus A, Cheng JF, Bruce DC, Goodwin LA, Pitluck S, Chertkov O, Zhang X, Detter JC, Han CS, Tapia R, Land M, Hauser LJ, Chang YJ, Kyrpides NC, Ivanova NN, Ovchinnikova G, Woyke T, Brumm C, Hochstein R, Schoenfeld T, and Brumm P (2012) Complete Genome Sequence of Paenibacillus strain Y4.12MC10, a Novel Paenibacillus lautus strain Isolated from Obsidian Hot Spring in Yellowstone National Park, Stand Genomic Sci 6, 381-400. [PubMed: 23408395]

[48]. Brouwer MS, Warburton PJ, Roberts AP, Mullany P, and Allan E (2011) Genetic organisation, mobility and predicted functions of genes on integrated, mobile genetic elements in sequenced strains of Clostridium difficile, PLoS One 6, e23014. [PubMed: 21876735]

[49]. Marin M, Martin A, Alcala L, Cercenado E, Iglesias C, Reigadas E, and Bouza E (2015) Clostridium difficile isolates with high linezolid MICs harbor the multiresistance gene cfr, Antimicrob Agents Chemother 59, 586-589. [PubMed: 25385106] 
[50]. Hansen LH, and Vester B (2015) A cfr-like gene from Clostridium difficile confers multiple antibiotic resistance by the same mechanism as the $c f r$ gene, Antimicrob Agents Chemother 59, 5841-5843. [PubMed: 26149991]

[51]. Candela T, Marvaud JC, Nguyen TK, and Lambert T (2017) A cfr-like gene cfr(C) conferring linezolid resistance is common in Clostridium difficile, Int J Antimicrob Agents 50, 496-500. [PubMed: 28663118]

[52]. Bianchi V, Eliasson R, Fontecave M, Mulliez E, Hoover DM, Matthews RG, and Reichard P (1993) Flavodoxin is required for the activation of the anaerobic ribonucleotide reductase, Biochem Biophys Res Commun 197, 792-797. [PubMed: 8267617]

[53]. Bianchi V, Reichard P, Eliasson R, Pontis E, Krook M, Jornvall H, and Haggard-Ljungquist E (1993) Escherichia coli ferredoxin NADP+ reductase: activation of E. coli anaerobic ribonucleotide reduction, cloning of the gene (fpr), and overexpression of the protein, J Bacteriol 175, 1590-1595. [PubMed: 8449868]

[54]. (2017) Kintek Explorer Chemical Kinetics Software, Kintek Corporation, www.kintekcorp.com.

[55]. Schwalm EL (2018) Investigation of the radical SAM methylases RlmN and Cfr, Ph.D. dissertation, The Pennsylvania State University, 68-85.

[56]. Pandelia M-E, Lanz ND, Booker SJ, and Krebs C (2015) Mössbauer spectroscopy of Fe/S proteins, Biochimica et Biophysica Acta BBA Molecular Cell Research 1853, 1395-1405. [PubMed: 25498248]

[57]. Moura I, Huynh BH, Hausinger RP, Le Gall J, Xavier AV, and Münck E (1980) Mossbauer and EPR Studies of Desulforedoxin from Desulfouibrio gigas * J. Biol. Chem 255, 2493-2498. [PubMed: 6244281]

[58]. Engstrom LM, Brinkmeyer MK, Ha Y, Raetz AG, Hedman B, Hodgson KO, Solomon EI, and David SS (2014) A zinc linchpin motif in the MUTYH glycosylase interdomain connector is required for efficient repair of DNA damage, J Am Chem Soc 136, 7829-7832. [PubMed: 24841533]

[59]. Nuñez NN, Khuu C, Babu CS, Bertolani SJ, Rajavel AN, Spear JE, Armas JA, Wright JD, Siegel JB, Lim C, and David SS (2018) The Zinc Linchpin Motif in the DNA Repair Glycosylase MUTYH: Identifying the $\mathrm{Zn}^{2+}$ Ligands and Roles in Damage Recognition and Repair, J Am Chem Soc 140, 13260-13271. [PubMed: 30208271]

[60]. Holm RH, Kennepohl P, and Solomon EI (1996) Structural and functional aspects of metal sites in biology, Chem Rev 96, 2239-2314. [PubMed: 11848828]

[61]. Czernuszewicz RS, Legall J, Moura I, and Spiro TG (1986) Resonance raman spectra of rubredoxin - new assignments and vibrational coupling mechanism from $\mathrm{Fe}-54 \mathrm{Fe}-56$ isotope shifts and variable-wavelength excitation, Inorg Chem 25, 696-700.

[62]. Lin IJ, Gebel EB, Machonkin TE, Westler WM, and Markley JL (2005) Changes in hydrogenbond strengths explain reduction potentials in 10 rubredoxin variants, Proc Natl Acad Sci U S A 102, 14581-14586. [PubMed: 16199518]

[63]. Lanz ND, and Booker SJ (2012) Identification and function of auxiliary iron-sulfur clusters in radical SAM enzymes, Biochim Biophys Acta 1824, 1196-1212. [PubMed: 22846545]

[64]. Lanz ND, and Booker SJ (2015) Auxiliary iron-sulfur cofactors in radical SAM enzymes, Biochim Biophys Acta 1853, 1316-1334. [PubMed: 25597998]

[65]. Davis KM, Schramma KR, Hansen WA, Bacik JP, Khare SD, Seyedsayamdost MR, and Ando N (2017) Structures of the peptide-modifying radical SAM enzyme SuiB elucidate the basis of substrate recognition, PNAS 114, 10420-10425. [PubMed: 28893989]

[66]. Lilla EA, and Yokoyama K (2016) Carbon extension in peptidylnucleoside biosynthesis by radical SAM enzymes, Nat Chem Biol 12, 905-907. [PubMed: 27642865]

[67]. Wei Y, Funk MA, Rosado LA, Baek J, Drennan CL, and Stubbe J (2014) The class III ribonucleotide reductase from Neisseria bacilliformis can utilize thioredoxin as a reductant, Proc Natl Acad Sci U S A 111, E3756-3765. [PubMed: 25157154]

[68]. Wei Y, Li B, Prakash D, Ferry JG, Elliott SJ, and Stubbe J (2015) A Ferredoxin Disulfide Reductase Delivers Electrons to the Methanosarcina barkeri Class III Ribonucleotide Reductase, Biochemistry 54, 7019-7028. [PubMed: 26536144] 
[69]. Wei Y, Mathies G, Yokoyama K, Chen J, Griffin RG, and Stubbe J (2014) A chemically competent thiosulfuranyl radical on the Escherichia coli class III ribonucleotide reductase, J Am Chem Soc 136, 9001-9013. [PubMed: 24827372]

[70]. Dong M, Su X, Dzikovski B, Dando EE, Zhu X, Du J, Freed JH, and Lin H (2014) Dph3 is an electron donor for Dph1-Dph2 in the first step of eukaryotic diphthamide biosynthesis, J Am Chem Soc 136, 1754-1757. [PubMed: 24422557]

[71]. Zhang Y, Zhu X, Torelli AT, Lee M, Dzikovski B, Koralewski RM, Wang E, Freed J, Krebs C, Ealick SE, and Lin H (2010) Diphthamide biosynthesis requires an organic radical generated by an iron-sulphur enzyme, Nature 465, 891-896. [PubMed: 20559380]

[72]. Maiocco SJ, Grove TL, Booker SJ, and Elliott SJ (2015) Electrochemical Resolution of the [4Fe-4S] Centers of the AdoMet Radical Enzyme BtrN: Evidence of Proton Coupling and an Unusual, Low-Potential Auxiliary Cluster, J Am Chem Soc 137, 8664-8667. [PubMed: 26088836]

[73]. Crowe-McAuliffe C, Graf M, Huter P, Takada H, Abdelshahid M, Nováček J, Murina V, Atkinson GC, Hauryliuk V, and Wilson DN (2018) Structural basis for antibiotic resistance mediated by the Bacillus subtilis ABCF ATPase VmlR, Proc Natl Acad Sci U S A 115, 89788983. [PubMed: 30126986]

[74]. Dönhöfer A, Franckenberg S, Wickles S, Berninghausen O, Beckmann R, and Wilson DN (2012) Structural basis for TetM-mediated tetracycline resistance, Proc Natl Acad Sci U S A 109, 16900-16905. [PubMed: 23027944]

[75]. Dingle KE, Elliot B, Robinson E, Griffiths D, Eyre DW, Stoesser N, Vaughan A, Golubchik T, Fawley WN, Wilcox MH, Peto TE, Walker AS, Riley TV, Crook DW, and Didelot X (2013) Evolutionary history of the Clostridium difficile pathogenicity locus, Genome Biol Evol. 6, 3652. 

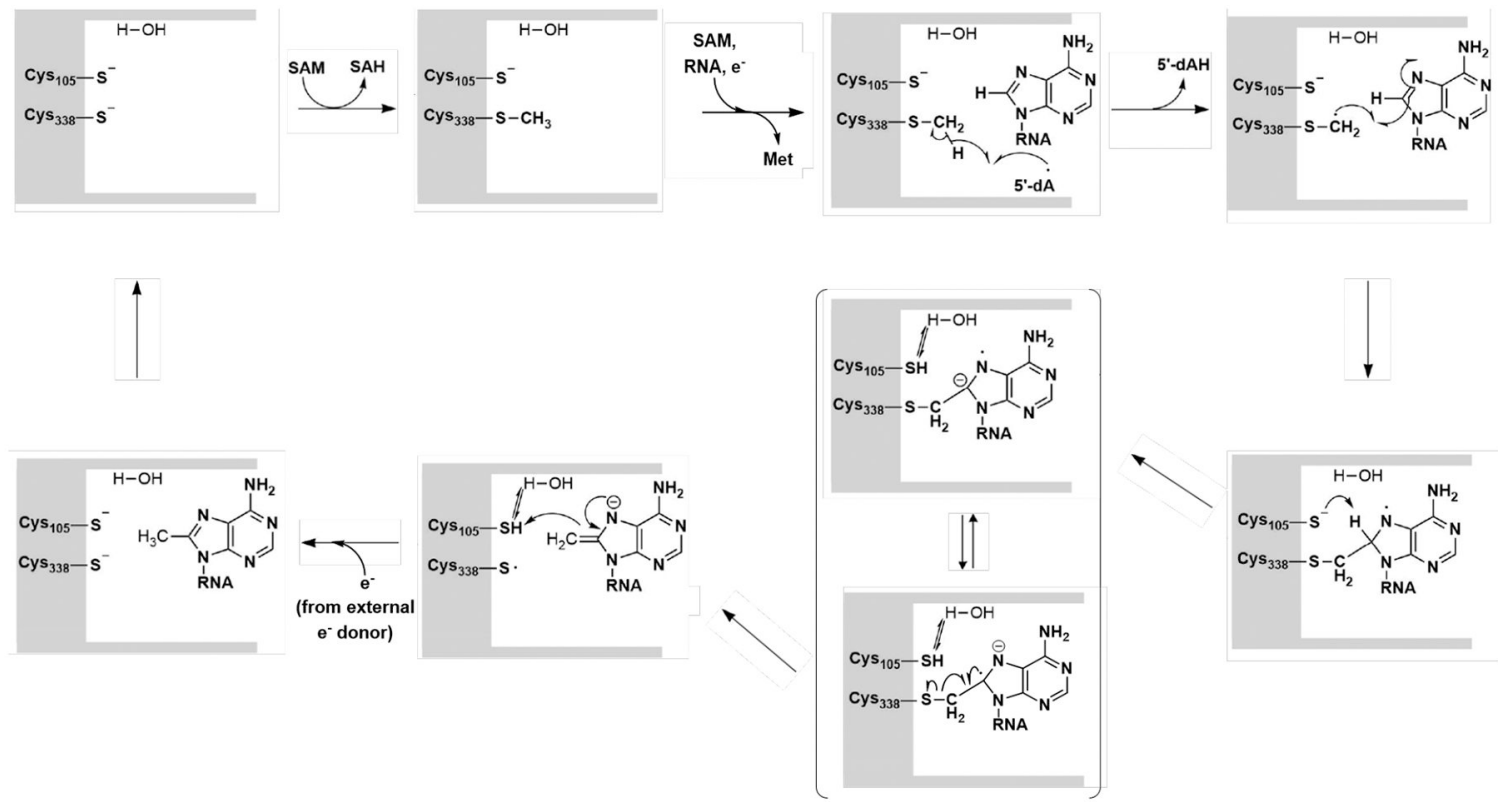

Figure 1. Proposed mechanism of C8 adenine methylation by Cfr. $7,13,14$

Schematic diagram of the catalytic Cys residues located in the Cfr RNA binding pocket (gray box) and the A2503 rRNA target nucleobase. 


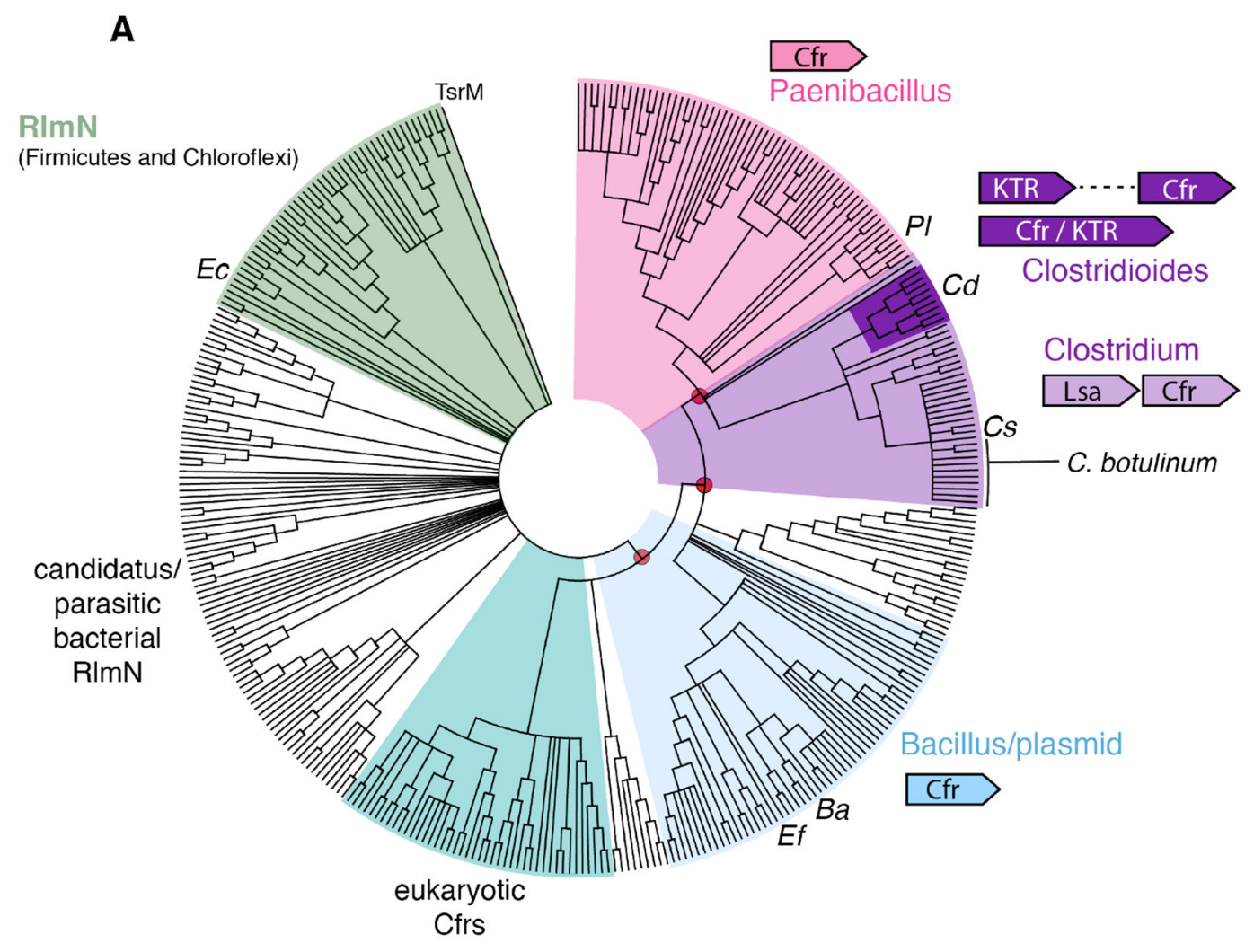

B

$B a, E f$, Sa, PI, Cs Cfr N
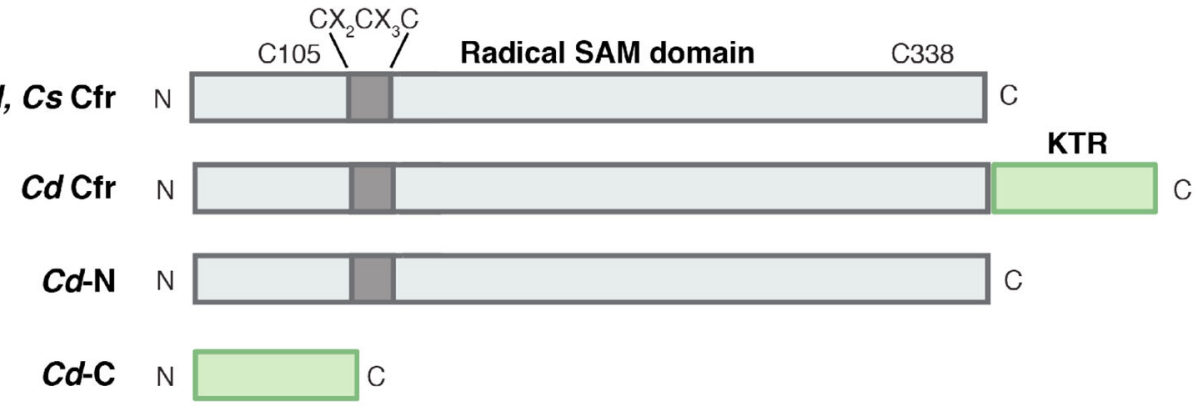

Figure 2. Selection of phylogenetically diverse Cfr enzymes for biochemical characterization. (A) Minimum evolution phylogenetic tree containing 361 representative sequences obtained by NCBI BLAST. The sequence of $S a \mathrm{Cfr}$ was the initial query. Bootstrap values (1000 replicates) were calculated for branch support and red circles denote values $>85 \%$ in selected branches. Dominant genera and the genomic context in each cluster are indicated in colored text/schematics. (B) Cartoon diagram of the domain architecture in Cfrs selected for study. Locations of conserved Cys residues ( $S a$ numbering) in the radical SAM domain are shown. 
A

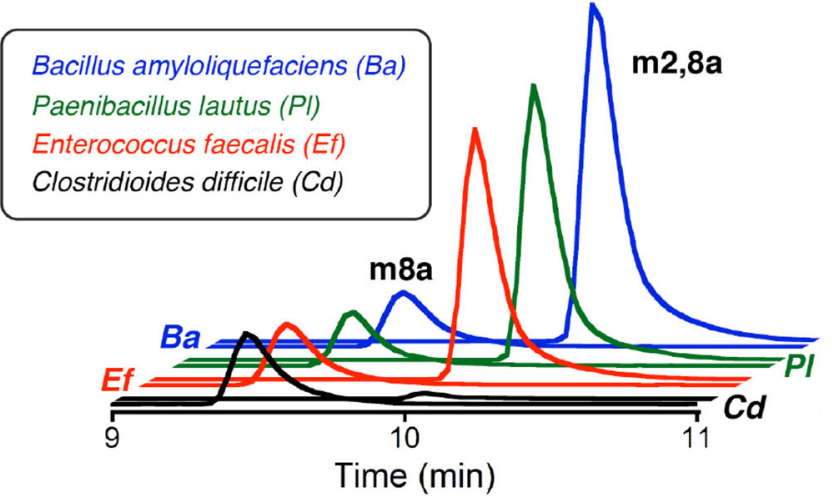

Time (min)
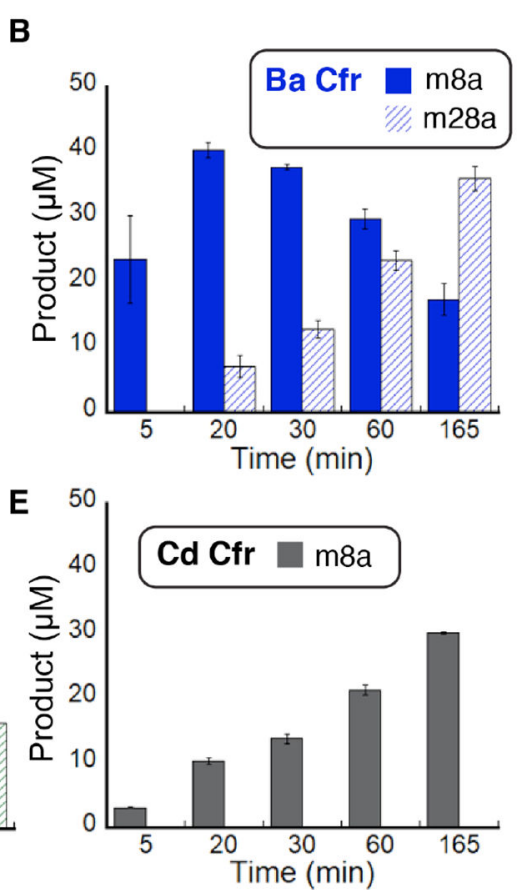

Figure 3. Methylation of a 155mer rRNA substrate by Cfr enzymes under limiting substrate conditions initiated with a protein-based reductant.

Reactions used the $E c$ Flv/Flx/NADPH reducing system in mixtures containing $100 \mathrm{mM}$ EPPS, pH 8, $10 \mathrm{mM} \mathrm{MgCl} 2,12.5 \%$ glycerol, 250 mM KCl, $200 \mu \mathrm{M}$ Flv, $20 \mu \mathrm{M}$ Flx, $2 \mathrm{mM}$ NADPH, $1 \mathrm{mM}$ SAM, $50 \mu \mathrm{M}$ 155mer RNA, and $48 \mu \mathrm{M}$ protein. (A) LC-MS analysis of methylated RNA products via single-ion monitoring at $\mathrm{m} / z=282.1$ (bottom trace, $\mathrm{m} 8 \mathrm{~A}$ ) and $\mathrm{m} / z=296.1$ (top trace, $\mathrm{m} 2,8 \mathrm{~A}$ ). Time course experiment monitoring formation and decay of singly-methylated $\mathrm{m} 8 \mathrm{~A}$ (solid bars) and doubly methylated $\mathrm{m} 2,8 \mathrm{a}$ (patterned bars) with (B) $B a \mathrm{Cfr}$, (C) $E f \mathrm{Cfr}$, (D) $P I \mathrm{Cfr}$, and (E) $C d \mathrm{Cfr}$. Error bars correspond to standard deviation of three averaged trials. 

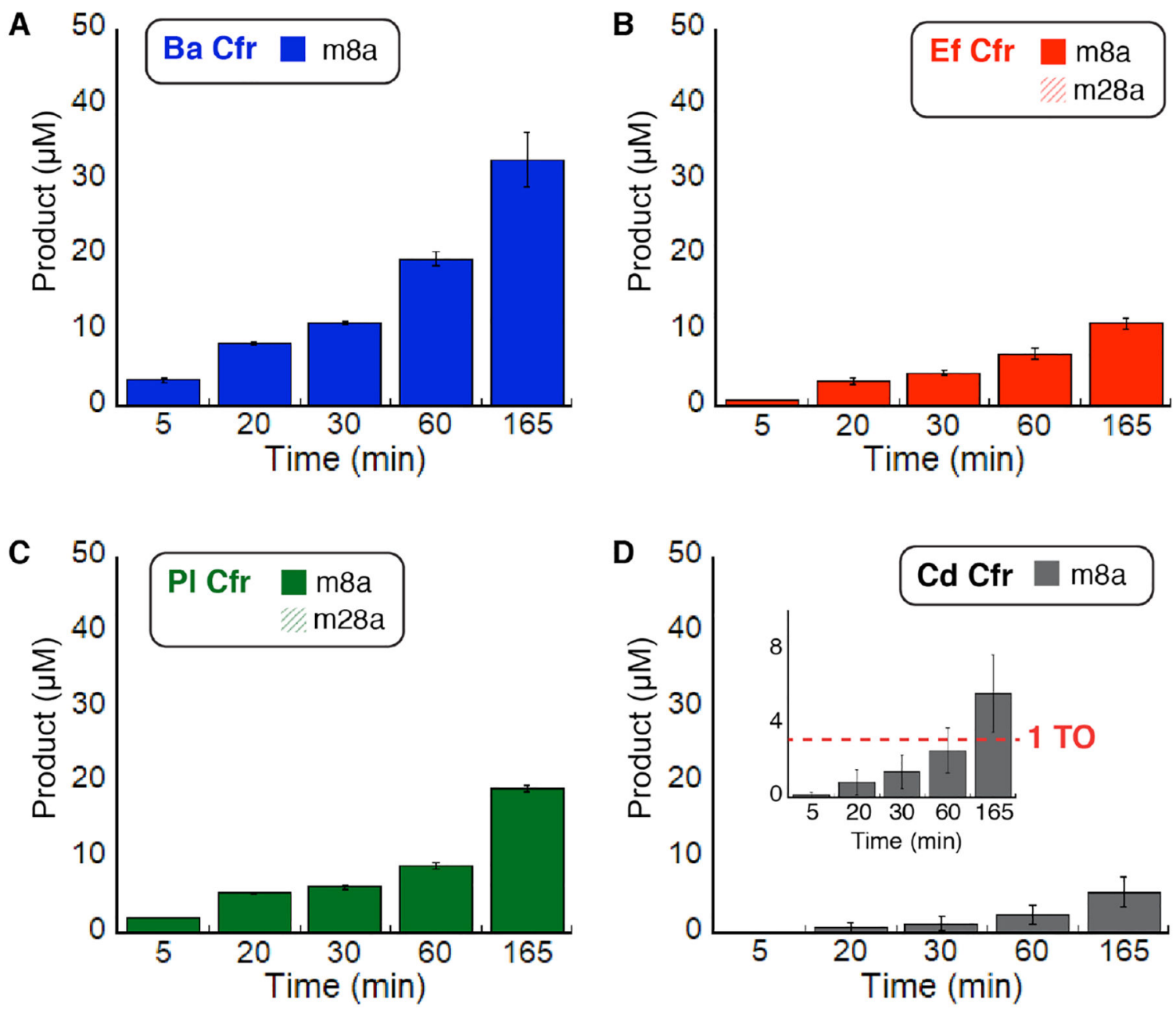

Figure 4. Methylation of a 155mer rRNA by Cfr enzymes with excess substrate in reactions initiated with a protein-based reductant.

Reactions used the $E c$ Flv/Flx/NADPH reducing system in mixtures containing $100 \mathrm{mM}$ EPPS, pH 8, $10 \mathrm{mM} \mathrm{MgCl}_{2}, 12.5 \%$ glycerol, 250mM KCl, $200 \mu \mathrm{M}$ Flv, $20 \mu \mathrm{M}$ Flx, 2 mM NADPH, $1 \mathrm{mM}$ SAM, $100 \mu \mathrm{M}$ 155mer RNA, and $3 \mu \mathrm{M}$ protein. Time course experiment monitoring formation and decay of singly-methylated m8A with (A) Ba Cfr, (B) EfCfr, (C) $P I C f r$, and (D) $C d$ Cfr. Error bars correspond to standard deviation of three averaged trials. The inset in panel D shows that $C d$ Cfr can promote multiple turnovers (red line). 


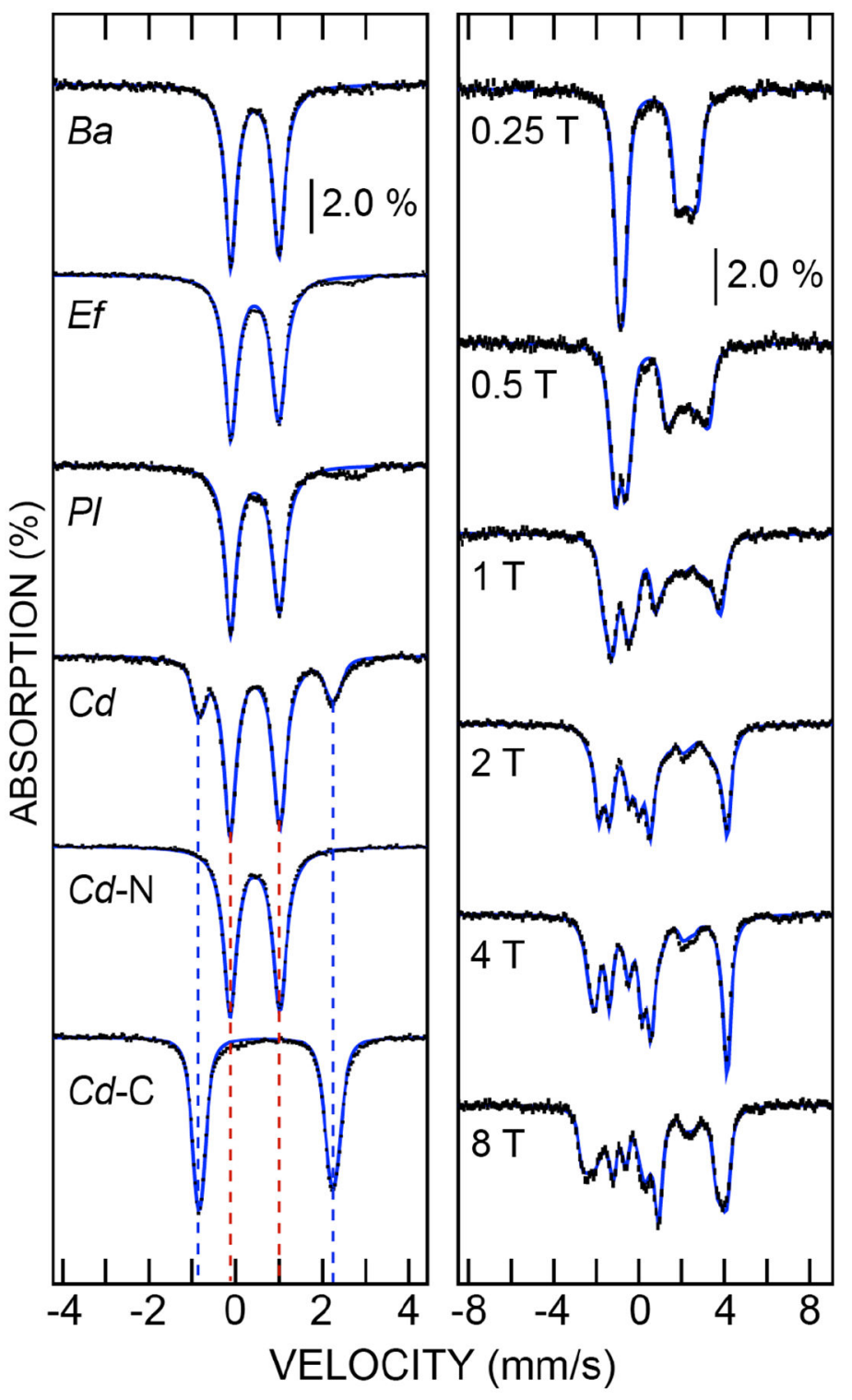

Figure 5. Mössbauer spectra of Cfr enzymes.

Left panel: comparison of reconstituted samples of $\mathrm{Cfr}$ from Bacillus amyloliquefaciens (Ba), Enterococcus faecalis (Ef), Paenibacillus lautus (PI), and Clostridioides difficile (Cd). Spectra of N-terminal and C-terminal truncations of $C d C f r$ are also shown; features of the $[4 \mathrm{Fe} 4 \mathrm{~S}]^{2+}$ cluster and ferrous rubredoxin-like site are denoted by red and blue dashed lines, respectively. Right panel: Mössbauer spectra of the C-terminal domain of $C d \mathrm{Cfr}$ in varying applied magnetic fields. Experimental data are displayed as black vertical bars, with simulations overlaid (blue solid lines). 
A

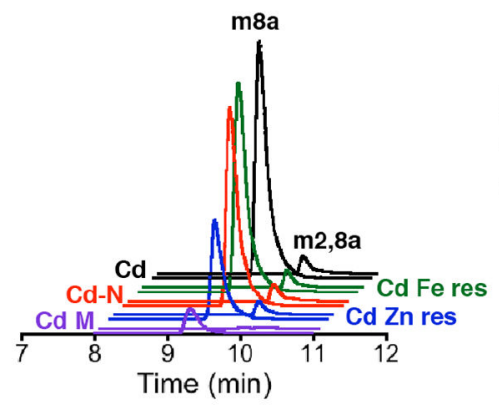

B

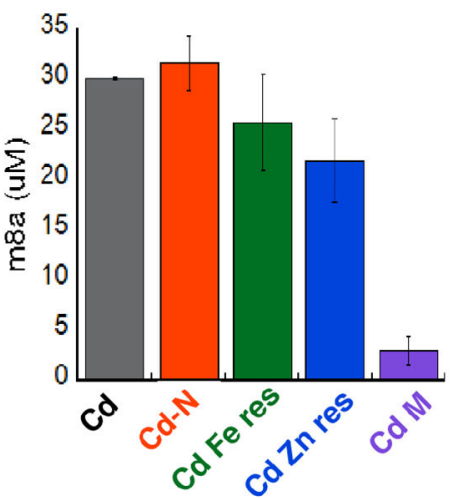

C

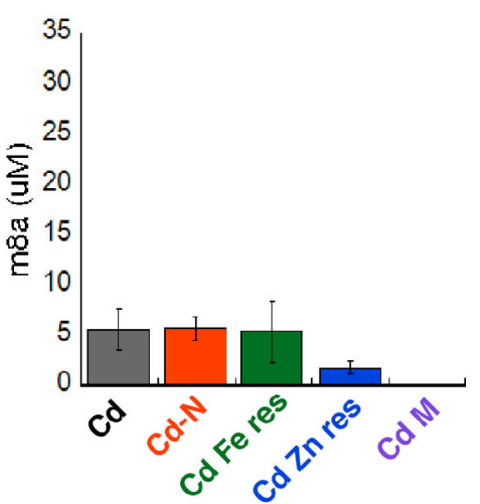

Figure 6. Methylation of a 155mer rRNA substrate by variant $C d$ Cfr enzymes under limiting substrate and excess substrate conditions and initiated by a protein-based reductant.

Reactions were performed with the $E c$ Flv/Flx/NADPH reducing system in mixtures containing $100 \mathrm{mM}$ EPPS, pH 8, $10 \mathrm{mM} \mathrm{MgCl} 2,12.5 \%$ glycerol, $250 \mathrm{mM} \mathrm{KCl}, 200 \mu \mathrm{M}$ Flv, $20 \mu \mathrm{M}$ Flx, and 2mM NADPH. (A) Limiting substrate LC-MS analysis of methylated RNA products via single-ion monitoring at $\mathrm{m} / z=282.1$ (bottom trace, $\mathrm{m} 8 \mathrm{~A}$ ) and $\mathrm{m} / \mathrm{z}=$ 296.1 (top trace, m2,8A). Cd-N = radical SAM domain only, $\mathrm{Cd}-\mathrm{C}=\mathrm{C}$-terminal KTR domain with $\mathrm{Fe}^{2+}$ or $\mathrm{Zn}^{2+}, \mathrm{Cd}-\mathrm{M}=\mathrm{C} 363 \mathrm{~A}$ variant (full-length), rescue (res) experiments contain $\mathrm{Cd}-\mathrm{C}$ added to $\mathrm{Cd}-\mathrm{N}$ in trans. Endpoint analysis (165 min) of the formation of singly-methylated m8A under (B) limiting substrate and (C) excess substrate conditions. Error bars correspond to standard deviation of three averaged trials. 
A

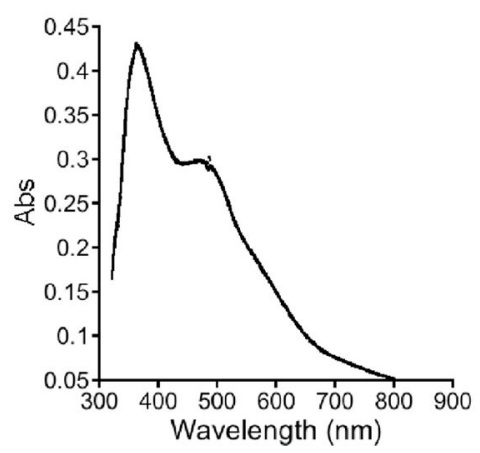

B

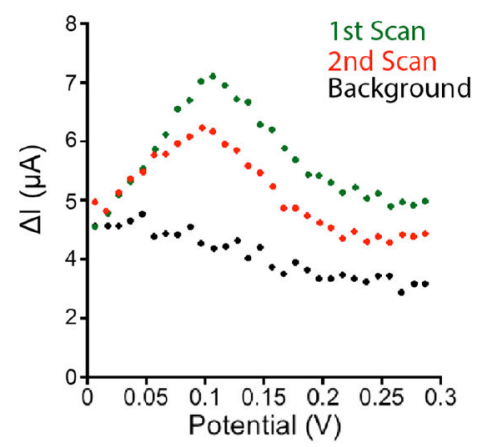

C

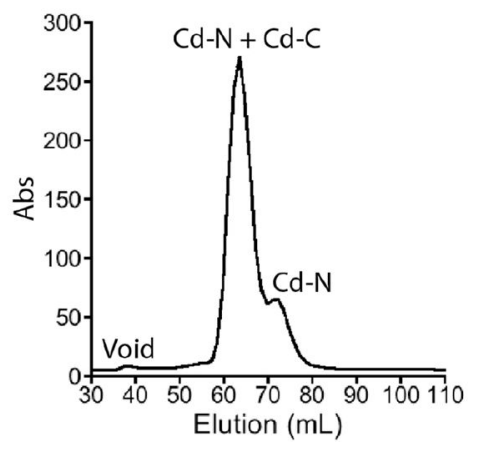

D

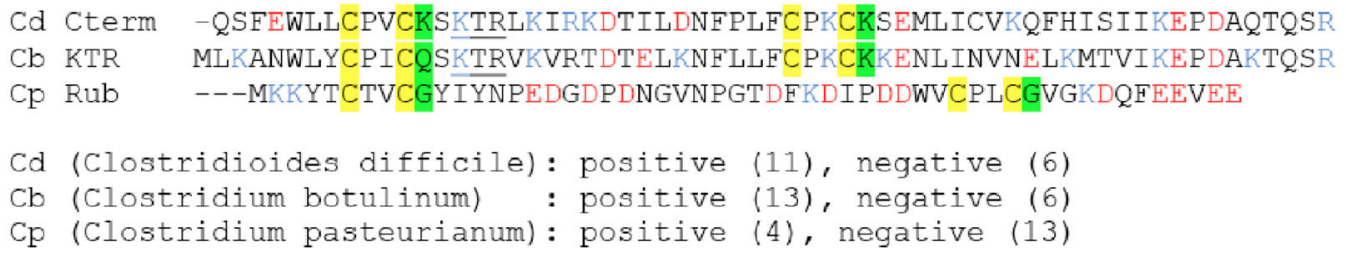

Figure 7. Electrochemical and UV-visible characterization of Cd C-terminal domain. (A) UV-visible difference spectrum of the oxidation of the $\mathrm{C}$-terminal domain of $\mathrm{Cd} \mathrm{Cfr}$. Absorbance maxima are visible at $370 \mathrm{~nm}, 485 \mathrm{~nm}$, and $582 \mathrm{~nm}$. (B) Square-wave voltammogram of KTR domain of $C d$ Cfr. The midpoint potential is $+106 \mathrm{mV}$. (C) Size exclusion chromatogram illustrating the interaction of $\mathrm{Cd}-\mathrm{N}$ and $\mathrm{Cd}-\mathrm{C}$ through co-elution. (D) Comparison of the $\mathrm{C}$-terminal domain of $\mathrm{Cd} \mathrm{Cfr}(\mathrm{Cd}-\mathrm{C})$, the KTR from $\mathrm{Cb}$, and the rubredoxin from $C p$. Metal coordinating cysteine pairs are highlighted in yellow, the structurally important residues directly following are highlighted in green, the positively charged residues are colored blue, and the negatively charged residues are colored red. The number of positively and negatively charged residues (bottom, numbers in parentheses) differentiates cys-rich KTRs from typical rubredoxins. 
A
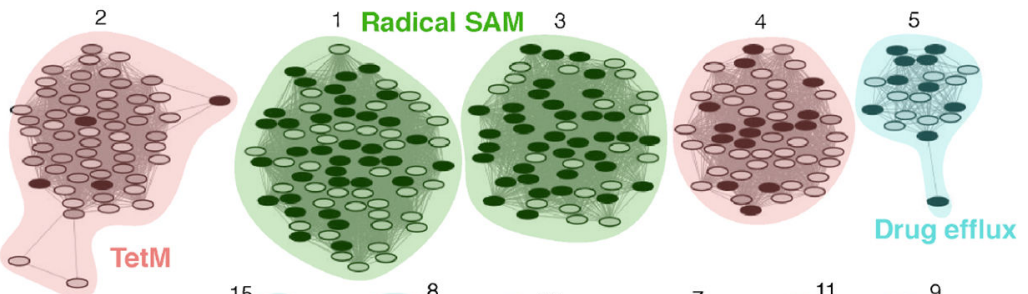

$688^{\circ}$ o $0^{15}$

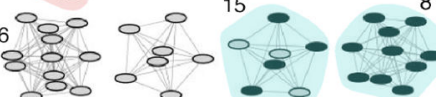

3800
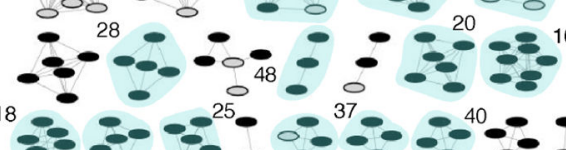

8000

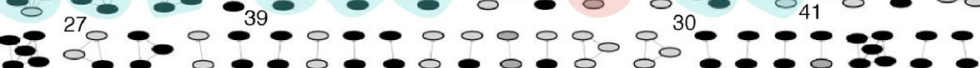

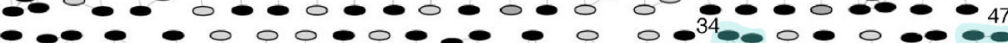

-

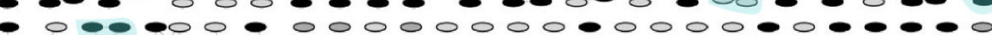

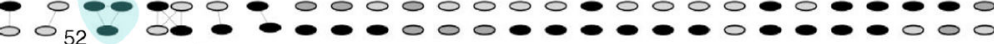

Clostridia

Bacilli

$\bigcirc$ Other/Unclassified

B Radical SAM (3)

Clostridium bolteae

$\square$ Cys-rich KTR $\square$ Radical SAM methylase $\square$ Drug efflux

$\square$ Helix-turn-helix $\square$ TetM / TetM leader

TetR regulator

$\square$ Sigma-70 $\square$ Transpon insertion cys-rich
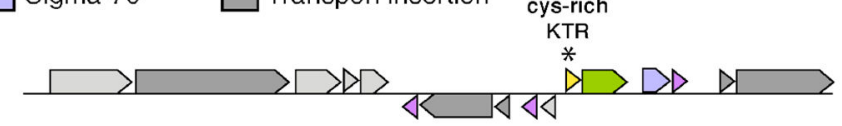

TetM (2)

Streptococcus suis
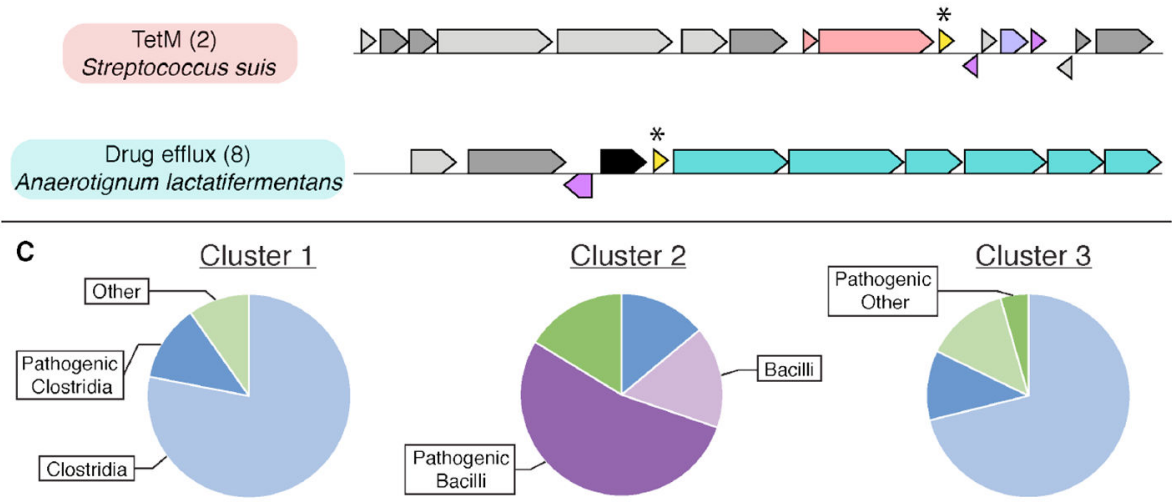

Figure 8. Sequence similarity and genome neighborhood network analyses of stand-alone Cysrich KTR proteins.

(A) SSN of IPR025957 constructed with an alignment score of 31. Nodes are arranged in an organic layout and each represents a single sequence. Nodes are shaded by host organism and colored by co-occurring gene type. Clusters without numbering represent groups that do not fall into one of the three major gene type categories. Additional clusters numbering two or less are not shown. (B) Representative gene clusters from each major category as determined by GNN analysis ( \pm 10 ORFs, $\geq 5 \%$ co-occurrence). Host organism and cluster number are displayed (left). KTR proteins are marked by a “*” symbol. (C) Breakdown by organism type in each of the first three SSN clusters. Clostridia = blue, Bacilli = purple, and other $=$ green. Pathogenic organisms are highlighted with dark shading and non-pathogens are shown in light shading. 
A

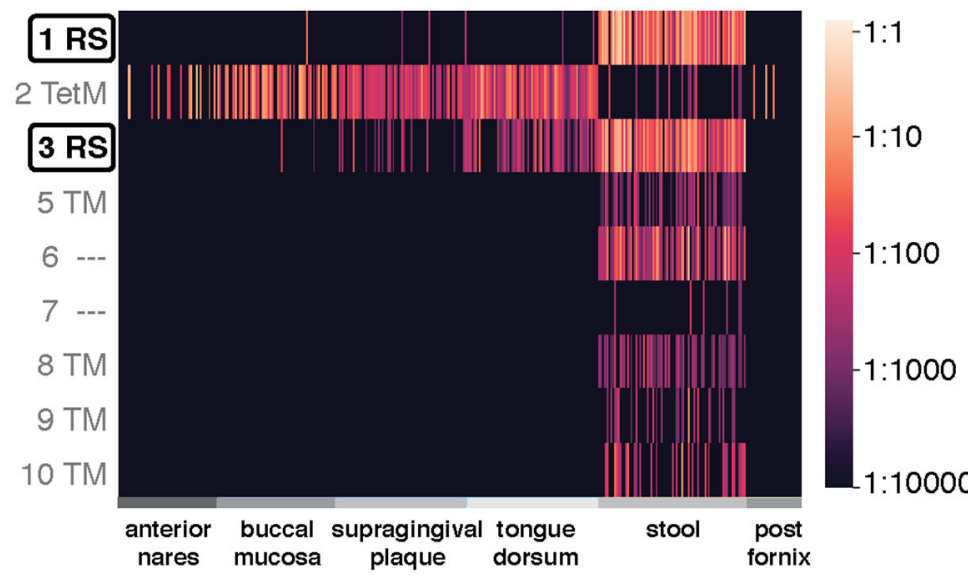

\section{KTR copies}

per microbial genome
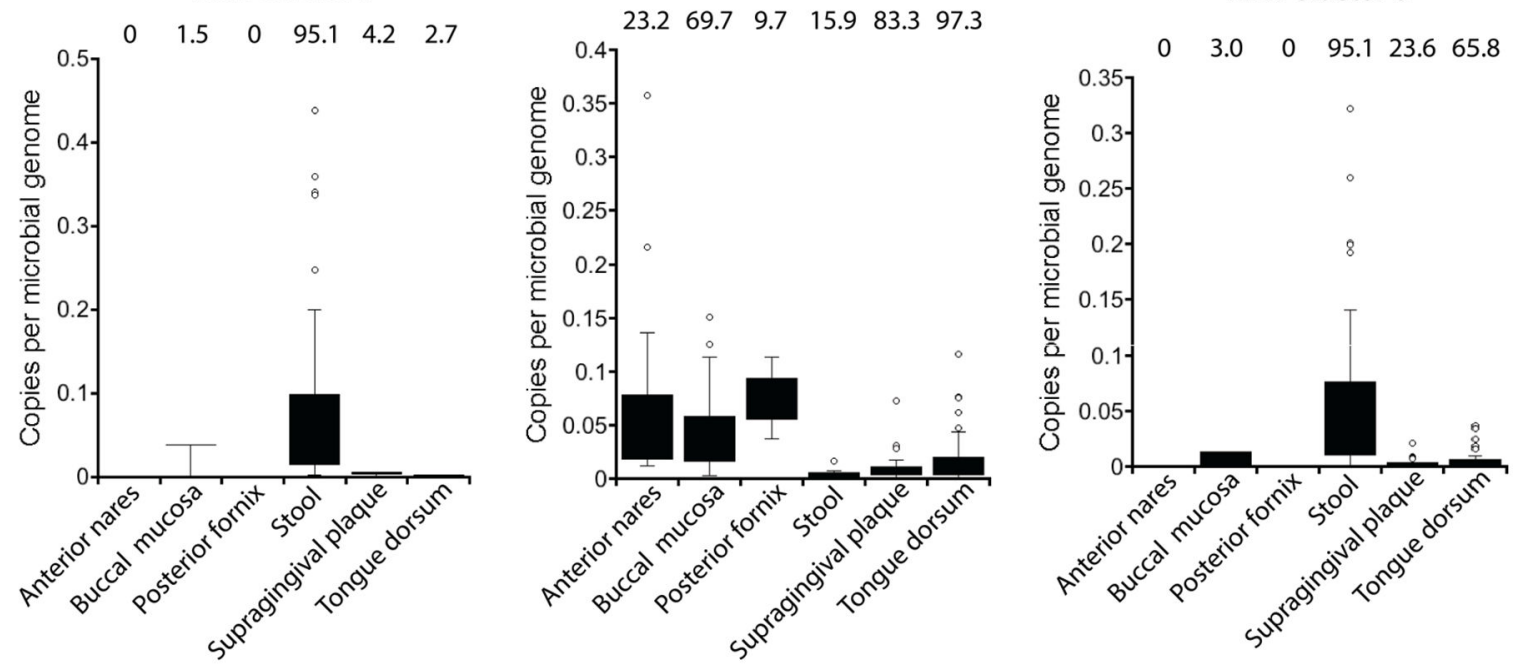

Figure 9. Metagenome abundance of KTR proteins in healthy human microbiome samples. (A) Heatmap for clusters 1-10 in the KTR SSN (see Fig. 8) showing marker abundance in 380 HMP datasets collected from six different areas of the body. Cluster 4 is omitted due to low abundance in the metagenomic sample set. (B-D) Box plots of the per-site abundance for the top three clusters. This analysis shows that the KTR proteins encoded adjacent to radical SAM enzymes are abundant in the gut microbiome. 
Table 1.

Sequence identity for Cfr homologs tested for RNA methylation.

\begin{tabular}{|c|c|c|c|c|c|}
\hline Homolog & $\begin{array}{c}\text { Bacillus } \\
\text { amyloliquefaciens }(\boldsymbol{B a})\end{array}$ & $\begin{array}{c}\text { Enterococcus } \\
\text { faecalis }(\text { Ef })\end{array}$ & $\begin{array}{c}\text { Paenibacillus lautus } \\
(\text { Pl })\end{array}$ & $\begin{array}{c}\text { Clostridioides } \\
\text { difficile }(\text { Cd })\end{array}$ & $\begin{array}{c}\text { Clostridium } \\
\text { sporogenes }(\boldsymbol{C s})\end{array}$ \\
\hline$\% \mathrm{ID}(\mathrm{Sa} \mathrm{Cfr})$ & 75.8 & 74.1 & 51.5 & 55.7 & 57.2 \\
\hline
\end{tabular}


Table 2.

Iron incorporation for Cfr homologs analyzed by Mössbauer spectroscopy.

\begin{tabular}{|lcccc|}
\hline Homolog & Fe/protein & Cluster & Area of subspectrum (\%) & Cofactor/protein \\
\hline Clostridioides difficile & 4.4 & $\begin{array}{c}{[4 \mathrm{Fe}-4 \mathrm{~S}]^{2+}} \\
\mathrm{Fe}^{2+} \mathrm{Cys}_{4}\end{array}$ & $\begin{array}{l}77 \\
22\end{array}$ & 0.8 \\
& 4.2 & {$[4 \mathrm{Fe}-4 \mathrm{~S}]^{2+}$} & 97 & 1.0 \\
\hline Enterococcus faecalis & 3.9 & {$[4 \mathrm{Fe}-4 \mathrm{~S}]^{2+}$} & 94 & 0.9 \\
\hline Paenibacillus lautus & 4.6 & {$[4 \mathrm{Fe}-4 \mathrm{~S}]^{2+}$} & 100 & 1.2 \\
\hline Bacillus amyloliquefaciens & & & & \\
\hline
\end{tabular}


Table 3.

Liquid chromatography elution gradient.

\begin{tabular}{|l|l|l|}
\hline Time (min) & A & B \\
\hline $0.0-5.0$ & $95 \%$ & $5 \%$ \\
\hline $5.0-6.5$ & $87 \%$ & $13 \%$ \\
\hline $6.5-7.0$ & $73 \%$ & $27 \%$ \\
\hline $7.0-8.0$ & $47 \%$ & $53 \%$ \\
\hline $8.0-12.0$ & $95 \%$ & $5 \%$ \\
\hline
\end{tabular}

